\title{
Egyptian sculptures from Imperial Rome. Non-destructive characterization of granitoid statues through macroscopic methodologies and in situ XRF analysis
}

\author{
Sander Müskens ${ }^{1}$ (D) Dennis Braekmans ${ }^{2,3} \cdot$ Miguel John Versluys $^{1} \cdot$ Patrick Degryse $^{4}$
}

Received: 4 October 2016 / Accepted: 16 December 2016 / Published online: 3 January 2017

(C) The Author(s) 2017. This article is published with open access at Springerlink.com

\begin{abstract}
Aegyptiaca-like Domitian's obelisk is now decorating Bernini's fountain on Piazza Navona or the Egyptian lions flanking Michelangelo's stairs towards the Capitol figure prominently amidst Rome's cultural heritage. Motivations for the import, contextualization, and copying of these objects during the Imperial Roman period are as heavily debated as they are ill understood. Provenance determination plays an important role in these discussions in terms of a (supposed) dichotomy between Egyptian (real) versus egyptianising (copy) but has only been applied stylistically and never been tested analytically. A scientific characterization of the materials themselves is even lacking altogether, as is an investigation into the cultural and symbolic meaning of the materials used. This paper is a first attempt to address these important lacunae on the basis of an explorative study of a selected sample of Egyptian statues from Rome. The identification and provenance attribution of the materials used for these statues are often problematic due to their relatively finegrained nature and dark color. Therefore, a full nondestructive analysis of Egyptian statues in dark-colored rocks
\end{abstract}

Sander Müskens

s.w.g.muskens@arch.leidenuniv.nl

1 Classical \& Mediterranean Archaeology, Faculty of Archaeology, Leiden University, Einsteinweg 2, 2333 CC Leiden, The Netherlands

2 Materials in Art and Archaeology, Laboratory of Materials Science, Delft University of Technology, Mekelweg 2, 2628 CD Delft, The Netherlands

3 Laboratory for Ceramic Studies, Faculty of Archaeology, Leiden University, Einsteinweg 2, 2333 CC Leiden, The Netherlands

4 Centre for Archaeological Sciences, Department of Earth and Environmental Sciences, KU Leuven, Celestijnenlaan 200E-bus 2408, 3000 Leuven, Belgium is presented in this study, with the stones evaluated by macroscopic examination and handheld X-ray fluorescence (XRF) analysis. The implemented methodology has allowed a distinction between greywacke and several varieties of granitoid rocks. In order to evaluate the potential for source attribution, a comparison was made between the results of our analyses and geochemical data for several granitoid rocks from Egypt. This has suggested Aswan as most likely source. The results presented here indicate that handheld XRF analysis can be used for the assessment of compositional variability in and potentially for the provenance of granitoid rocks, provided that a fine-grained area of the material can be measured on multiple locations, and if these values can be assessed on (in)consistencies with other published reference materials.

Keywords Aegyptiaca $\cdot$ Imperial Rome $\cdot$ Macroscopic rock classification · Non-destructive handheld XRF spectrometry · Provenance analysis

\section{Introduction}

Egyptian and egyptianising statues from Imperial Rome (socalled Aegyptiaca) form an eye-catching part of the city's cultural heritage in both the actual cityscape and Rome's museums. They testify to a process of cultural transference whereby Rome shows imperial conquest and world domination through Egyptian objects as trophies while simultaneously these (same) Egyptian objects constitute Rome as the cosmopolis by helping to build Rome's society, culture, and religion. What once was Egyptian, therefore, already soon seems to have become Roman. Besides the import of statues from Egypt, sometimes already centuries old, new sculptures with Egyptian themes were produced in the Roman world. Scholarship has traditionally understood these coexisting 
aspects of Egyptian sculpture in the Roman world as two essentially different phenomena. Thus, authentic Egyptian objects would mainly testify to Roman preoccupations with Egyptian religion and the cult of Isis in particular, while their derivative non-Egyptian and therefore less authentic counterparts, egyptianising copies, could also attest more generally to a Roman predilection for things exotic (Bosticco 1952; Quack 2003; Malaise 2005). Consequently, the (supposed) provenance of Aegyptiaca is often applied as a heuristic device to determine their archeological interpretation (for the category of Aegyptiaca, see Müskens 2014a). Provenance determination has, however, only been applied stylistically, based on an alleged direct relationship between cultural styles and geographic origin. The provenance of the materials themselves has not been involved in this discussion to date, despite its potential to add to the long-standing Egyptian versus egyptianising dichotomy. In fact, research on Aegyptiaca has so far empathically neglected the material aspects of Aegyptiaca in terms of both a scientific characterization of the material itself and the cultural-historical reasons for the use of particular materials.

Recent studies have shown the great potential of material culture studies for a better understanding of the socio-cultural role and impact of material culture (Degryse and Shortland 2013; Jones and Boivin 2010; Hollenback and Schiffer 2010; Brysbaert 2007). It has been demonstrated, for instance, that certain materials were sometimes deliberately used to evoke specific cultural and symbolic connotations. In the Roman world, this was particularly true for the wide range of exotically colored or patterned stones that ranked among the most sought after commodities of the Empire exactly because of the social implications of their materiality and, consequently, their potential to create specific meanings by actively capitalizing upon these implications. Many Aegyptiaca that circulated through the Roman world are made out of stone, and recent studies have just begun to show the relevance of a material approach for a more complete understanding of these objects (Müskens 2014b and 2017; Versluys et al. 2014; Bülow Clausen 2014). They demonstrate the necessity for a more integrated approach to Aegyptiaca from the Roman world. It has become clear that stylistic and iconographic analysis alone cannot provide full answers to questions about the motivations for their import, contextualization, and copyingall of which remain heavily debated and ill understood.

In order to enable a material perspective and to start exploring new directions of research, we are in need, first of all, of reliable characterizations of the materials themselves. The traditional focus on representative aspects of Aegyptiaca mentioned previously means that the stone materials have never been the subject of a proper analysis. As a result, there are many misidentifications in the existing literature and often geologically incorrect rock names are used in overviews like Malaise 1972, Roullet 1972, Lembke 1994, and Versluys
2002. A survey of relevant studies shows that this confusion relates in particular to more or less homogeneous, darkcolored stones. The dark stone of a male torso which is currently preserved in Palazzo Altemps in Rome is a good case in point (PA362624, Fig. 1i). It has previously been identified as "dunkles Hartgestein," "basalto nero," "basanite," and, most recently, "granodiorite" (Lembke 1994; Arslan 1997; 390 V. 7 [L. Sist]; Walker and Higgs 2001, 328-329 no. 347 [C. Alfano]; Candilio et al. 2011, 324 [L. Sist Russo], respectively). The confusion between dark-colored rock types such as basalt, greywacke, and granodiorite has been widely acknowledged in Egyptian archeological literature and resonates in more general terms with the problem of incorrect characterizations of archeological stone by non-specialist archeologists (Brown and Harrell 1998; Aston et al. 2000; Klemm and Klemm 2001; Bloxam et al. 2014; on the issue in general, Herz and Garrison 1998). The Rosetta Stone is one of the most illustrative examples of this practice. Although for many years it was assumed to be made of basalt, recent analysis determined that it was actually carved from granodiorite (Middleton and Klemm 2003). Cleaning revealed that the confusion was most likely due to a protective coating and accumulated dirt which had obscured the true appearance of the rock for years. This example is illustrative for the difficulties that may be encountered in identifying archeological stone materials, which is often further complicated by unfavorable lighting conditions in museum settings. Additionally, the
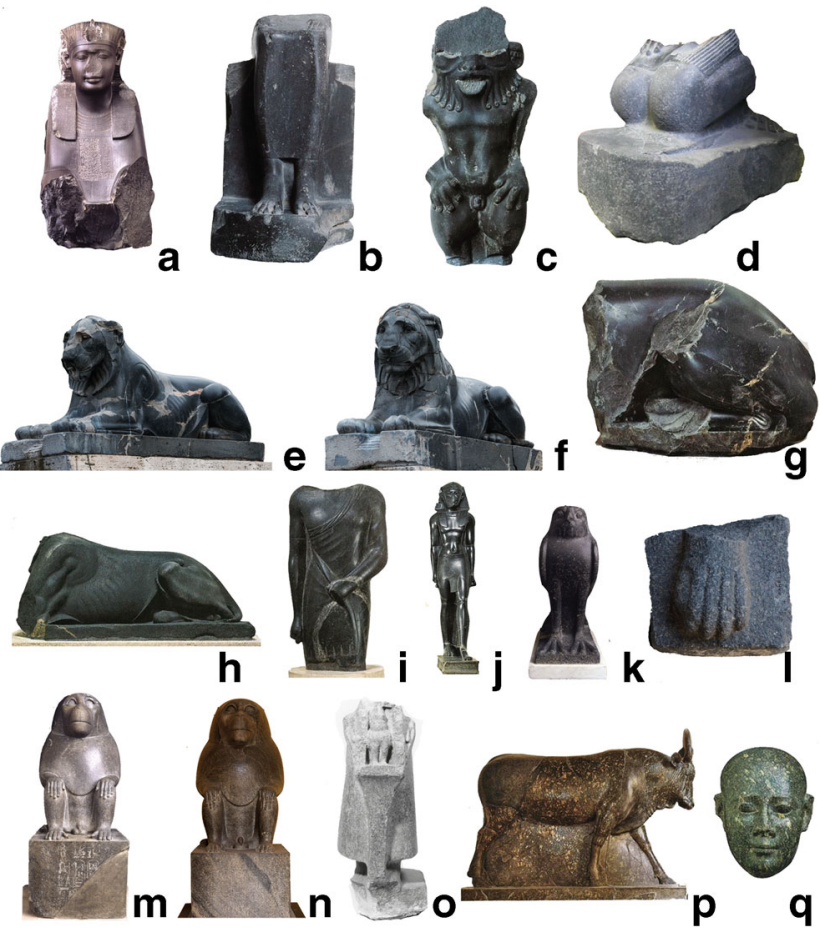

Fig. 1 a-q Overview of the statues included in this study. a MC35. b TD590. c TD56356. d TD no inv. e MC28. f MC30. g PA362624. h PA362622. i PA362623. j PA60921. k MC31. 1 PD514563. m MC26. n MC32. o MC2384. p PA182594. q PA112108. Further details in Table 1 
typically polished surfaces of archeological artifacts pose serious limitations to the possibilities for mineral and rock identification, especially in combination with fine-grained textures and dark colors.

Although several optical and chemical analytical methods are available to provide characterizations of and source discrimination between archeological stone materials, their specific sampling requirements often violate the nature of archeological artifacts (Kempe and Harvey 1983; Tykot 2004). This also applies to the Aegyptiaca in this study which require full non-destructive and in situ analysis. Therefore, we have explored macroscopic classification as described by Brown and Harrell (1991) as heuristic tool in this study. The preliminary data thus obtained were evaluated with handheld $\mathrm{X}$-ray fluorescence (HH-XRF) analysis to assess the chemical variability and determine potential source areas for the materials under study. In the last decades, the development of $\mathrm{HH}-$ XRF devices has allowed the non-destructive and in situ determination of the chemical composition of various archeological artifacts (Shugar and Mass 2012). Many studies have looked at obsidian (Glascock et al. 1999; Frahm 2014) and other types of rocks (Barbera et al. 2013; Palumbo et al. 2015), glass (Scott et al. 2012; Scott et al. 2014), ceramics (Goren et al. 2011; Barone et al. 2011; Speakman et al. 2011; Hunt and Speakman 2015), metals (Fernandes et al. 2013), and sediments (Neff et al. 2012). This type of analysis holds great potential for the characterization of all nonmoveable museum artifacts, but the results need to be carefully examined and contextualized to obtain meaningful results. In the remainder of this paper, we will explore the possibilities for full non-destructive and in situ analysis of the stone materials of a selected sample of seventeen Aegyptiaca from Imperial Rome. The following issues will be addressed: (1) rock classification of unknown dark-colored Egyptian statues from Rome and the potential of careful macroscopic examination with non-destructive in situ chemical analysis, (2) assessment of the validity and ability of HH-XRF to detect consistent and meaningful differences in granitoid composition, and (3) assessment of the possibility to determine an Egyptian origin for the studied rocks.

\section{Materials: the statues}

The selection of statues was primarily determined by an existing uncertainty over the identification of dark-colored rock types and the consequent need for reliable classifications of these materials in particular. Therefore, the studied sample includes seventeen Aegyptiaca from unknown dark-colored stone materials (Table 1 and Fig. $1 \mathrm{a}-\mathrm{q}$ ). The selected statues have all been found in Rome. In some cases, the Imperial Roman-use contexts are known, and it is evident that several statues once adorned the Iseum Campense, the sanctuary dedicated to the goddess Isis on the Campus Martius (Lembke 1994). Hieroglyphic inscriptions, typology, and stylistic features suggest that the majority of the selected Aegyptiaca were manufactured prior to the Roman period and subsequently transported from Egypt to Rome in the Roman Imperial period. Possible exceptions are the royal male statue (PA60921, Fig. 1j) and the statue of the god Apis (PA182594, Fig. 1p) which have been variably dated to the Ptolemaic and Roman periods (La Rocca and Parisi Presicce 2010; Candilio 2011; Manera and Mazza 2001).

\section{Analytical methods}

\section{Macroscopic rock classification and provenance hypotheses}

Provisional rock classifications were formulated on the basis of the recommendations for macroscopic rock classification by Brown and Harrell (1991). Adapted from internationally acknowledged non-macroscopic analytical methods, this classification is particularly suitable for the selected Aegyptiaca since it meets the requirements to study these objects nondestructively and in situ. In addition, a neodymium magnet was used to test the magnetic properties of minerals in the studied rocks. This is an easy way to determine the presence of certain iron-rich minerals, most notably magnetite, which is an important asset in identifying the genetic origin of rocks (Bourne 1993). This is of particular relevance for the present study, because the magnetic susceptibility of the studied rocks can be used as a diagnostic tool to distinguish between the most frequently mistaken rock types, namely greywacke, basalt, and granodiorite. Although a wide overlap has been reported between different rock types, sedimentary rocks have the lowest average magnetic susceptibility values and basic igneous rocks have the highest. This means that greywacke, a slightly metamorphosed sedimentary rock, will be much less susceptible to the neodymium magnet than granodiorite and especially basalt and intermediate and basic igneous rocks, respectively. Telford et al. (1990) report average magnetic susceptibility values of 70 for basalt and $0.4 / 0.9$ for sandstone/average sedimentary rocks, respectively $\left(\times 10^{3}\right.$, SI units); and Hernant (2003) reports maximum volume susceptibility values (SI units) of 0.18 for basalt, 0.062 for granodiorite, and 0.0012/0.0209 for silt/sandstone, respectively (cf. Clark and Emerson 1991; Hunt et al. 1995).

In this paper, we use the following size scale: fine, less than $1 \mathrm{~mm}$; medium, 1-5 mm; coarse, 5-30 mm; and very coarse, more than $30 \mathrm{~mm}$. The terms aphanitic and phaneritic are sometimes used to determine the degree of coarseness of rocks. Aphanitic rocks are rocks in which individual crystals are not distinguishable by the unaided eye. In phaneritic rocks, crystals are visible with the naked eye. Following the 


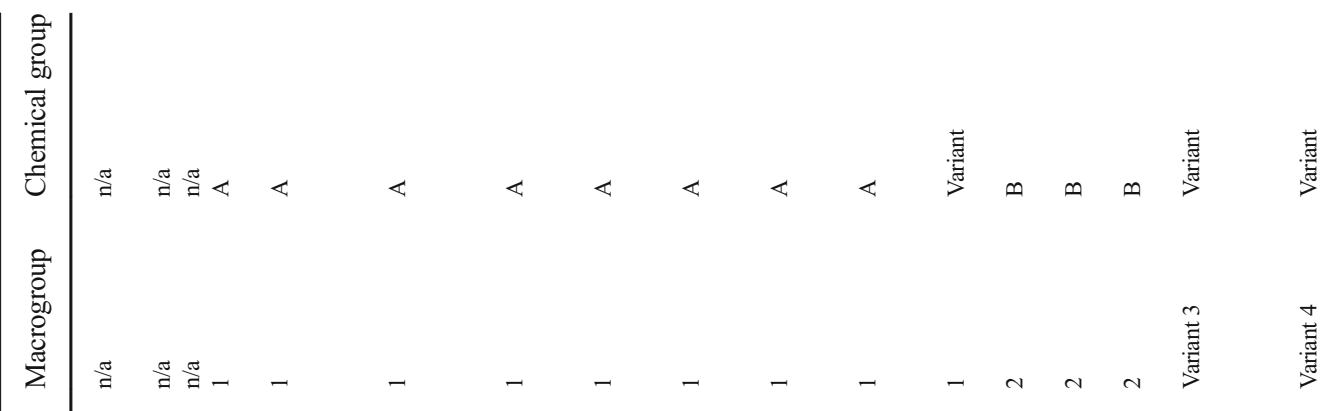

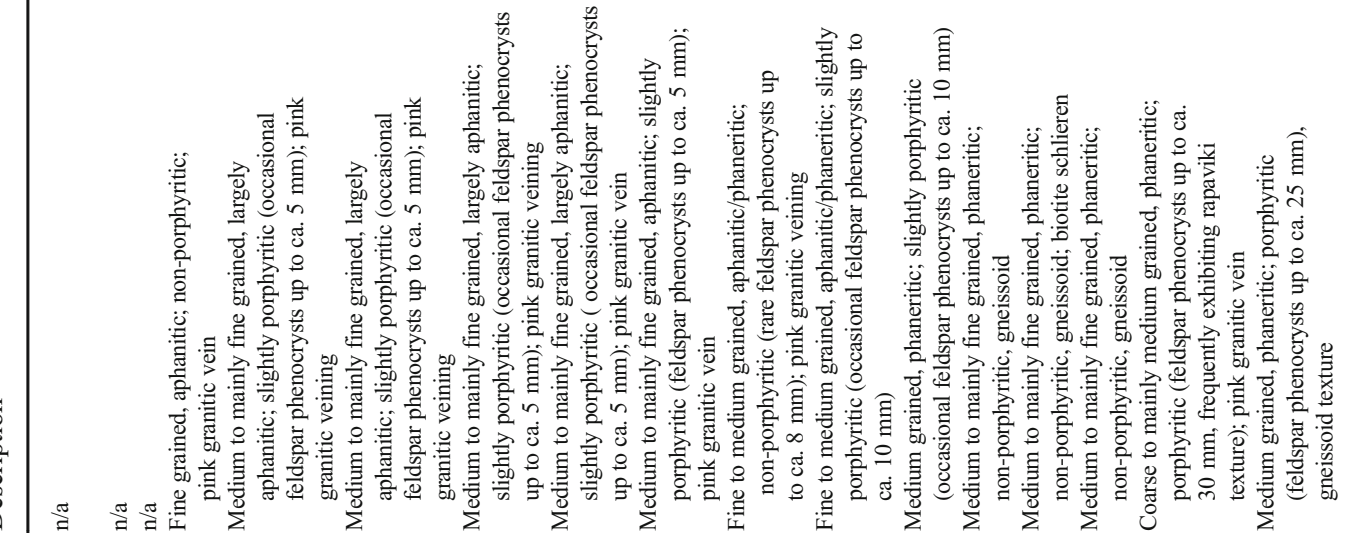

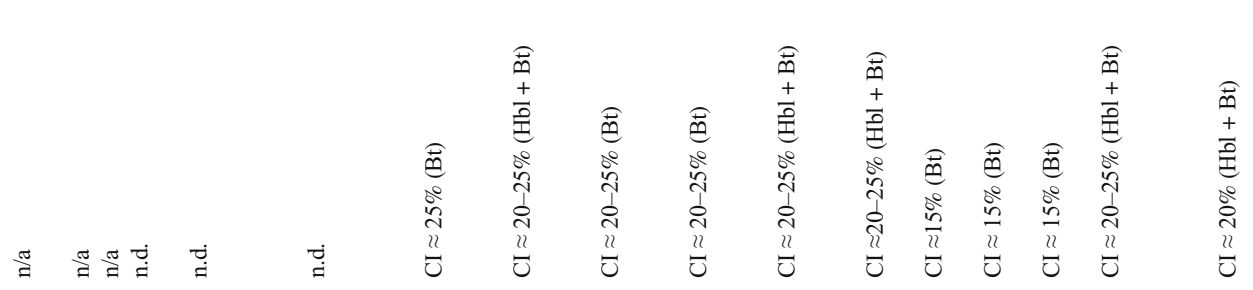

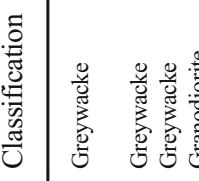

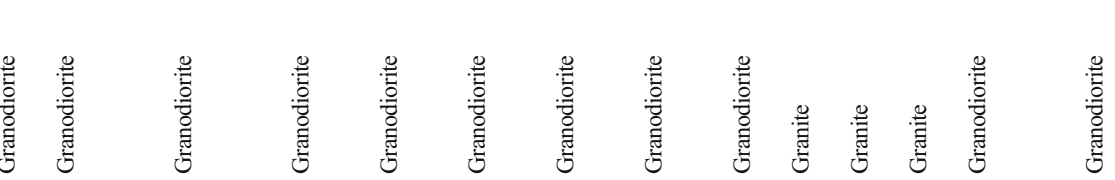

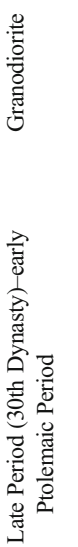

员离<smiles>C[C@H]1[C@H](C)[C@H]1C</smiles>

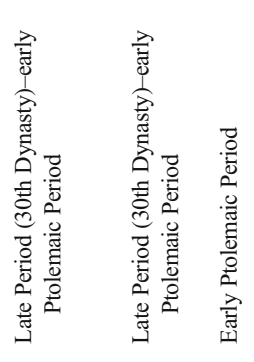

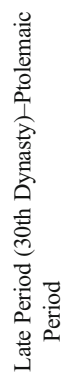

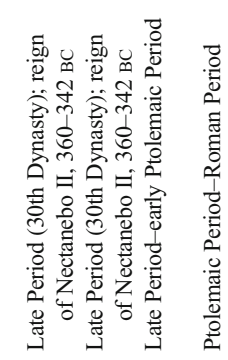

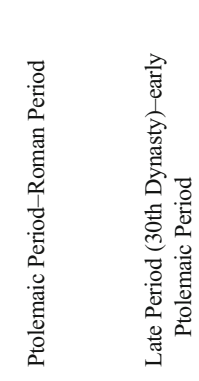

$\stackrel{\text { 音 }}{\mathrm{B}}$

赵

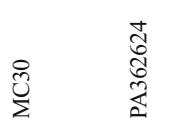

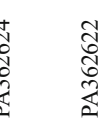

đั่

客

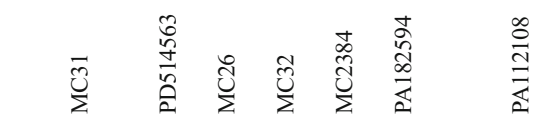

$\mid$

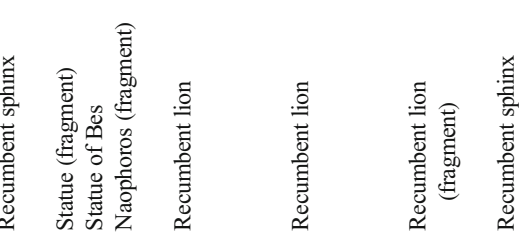

$\frac{0}{\frac{0}{2}}$

I

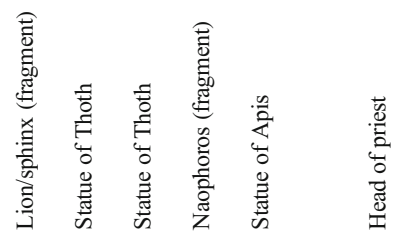


recommendations in Brown and Harrell (1991), the boundary between aphanitic and phaneritic rocks is set at $1 \mathrm{~mm}$ which means that all fine-grained rocks are considered aphanitic. Some rocks have grains in two different size ranges. These rocks are named porphyritic, with the larger crystals called phenocrysts. The terms euhedral, subhedral, and anhedral are used to describe the degree to which crystals have developed their typical crystal morphology. In descending order, these terms indicate how well crystals are shaped, which may help in mineral identification. Alkali feldspar phenocrysts sometimes cross over into plagioclase at their rims. Macroscopically, this appears as a white mantle around a pinkish core; occasionally, plagioclase phenocrysts also cross over into alkali feldspar at their rims, which appears at a macroscopic level as a pink mantle enveloping a plagioclase crystal. This is called rapaviki texture. Igneous rocks sometimes exhibit a (sub-)parallel arrangement of the feldspar and biotite grains. This type of foliation is caused by magmatic flowage rather than metamorphism. Igneous rocks with such textures are described as gneissoid rocks. Some igneous rocks contain irregular patches or streaks which appear as portions richer in biotite than the surrounding mass and therefore darker in color or as patches of coarser or finer grains than the main rock; these are known as schlieren. Color index, that is the ratio of dark-colored minerals to light-colored minerals in a rock (Le Maitre et al. 2002), was determined by visual approximation. Color index is a useful indicator of the presence of certain types of minerals in igneous rocks and therefore an important macroscopic asset in determining the specific rock type. Color descriptions were made according to the Munsell Rock Color Book (rev. ed. 2009). Where possible, potential source attributions were formulated through comparisons between the studied materials and the hand specimens of geological rock samples in the Ancient Egyptian Stone Collection (University of Toledo, Ohio; polished slabs of hand specimens from the Ancient Egyptian Stone Collection have been published online at http://www.eeescience.utoledo.edu/ faculty/harrell/Egypt/Quarries/Hardst Quar.html and will be referred to henceforth as $A E S C$, followed by the numbering system used on this website) and the Klemm Collection (British Museum, London).

\section{X-ray fluorescence analysis (HH-XRF)}

Handheld X-ray fluorescence equipment (Bruker Tracer III$\mathrm{SD}$ ) was used to determine the chemical composition of the rocks of the selected Aegyptiaca. The instrument is equipped with an Rh anode X-ray tube and a Peltier-cooled silicon drift detector ( $\sim 145 \mathrm{eV}$ at $\mathrm{Mn} \mathrm{Ka})$. Spot size is approximately 2 by $3 \mathrm{~mm}$. Because of the spot size of a HH-XRF device and homogeneity considerations, care was taken to concentrate analysis on the most fine-grained part of the different statues in order to achieve the most consistent bulk chemical data.

Measurements were taken in air for $300 \mathrm{~s}$, using a Cu-Ti-Al filter, with beam conditions of $40 \mathrm{keV}$ and $10.5 \mu \mathrm{A}$ for optimal excitation of elements from 17 to $40 \mathrm{keV}$ (Fig. 2). Light elements were measured under vacuum, without a filter, and beam conditions of $15 \mathrm{keV}$ and $25 \mu \mathrm{A}$. An empirical

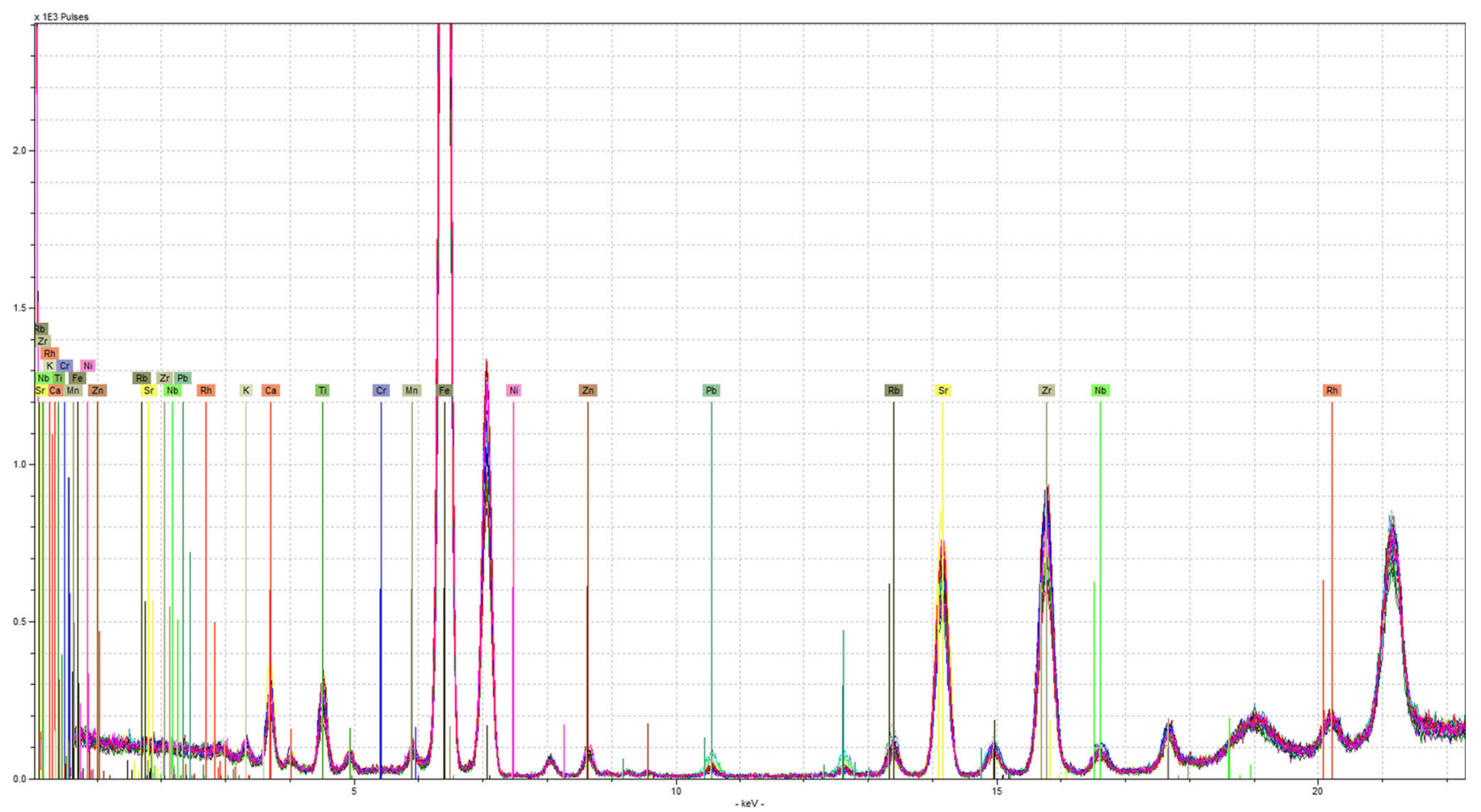

Fig. 2 Representative XRF spectrum of granodiorite group 1, measured for $300 \mathrm{~s}(40 \mathrm{kV}-10.5 \mu \mathrm{A})$ in a dry air environment 
calibration was used to semi-quantitatively determine the composition of the samples. In order to check accuracy and monitor for any machine drift during the analyses, a series of rock and soil standards were also analyzed. Prior to quantifying the spectra, all data was evaluated through the ARTAX software in order to determine the consistency of the matrices. A set of international certified standards was used to determine accuracy: BIR-1 (basalt), SRG-1 (shale), GSP-2 (granodiorite), 2710a (soil), 98b (sediment), and CRM667 (sediment). Only elements with sufficiently high squared correlation coefficients $\left(R^{2}\right)$ (intensities/certified value), as an assessment of accuracy, were retained for subsequent analysis: $\mathrm{Ca}=$ $0.90, \mathrm{Sr}=0.96, \mathrm{Ti}=0.99, \mathrm{Mn}=0.99, \mathrm{Fe}=0.98, \mathrm{Ni}=0.91, \mathrm{Zn}$ $=0.99, \mathrm{Zr}=0.98, \mathrm{Cr}=0.93$, and $\mathrm{K}=0.97$. Other elements did not provide any acceptable coefficients and were therefore not taken into account for the analyses. Precision (both repeatability and reproducibility) of the measurements was controlled at several instances by replicate analyses (no. 5) and is best assessed through the calculation of the relative standard deviation (RSD or \%RSD) (Abzalov 2008). All elements are well below 10\% RSD: Ca (1.78), Fe (0.88), K (4.87), Sr (1.33), Ti (3.41), Zn (5.78), $\mathrm{Cr}$ (3.19), and $\mathrm{Zr}$ (1.53), apart from $\mathrm{Ni}$ (9.97) (GSP2 and BIR1a).

The measurements were evaluated by an assessment of semi-quantitative data through bivariate diagrams as well as by means of multivariate statistical procedures such as principal component analysis (henceforward PCA). These statistical techniques were selected in order to structure the data and to explore potential chemical factors contributing to the variability between the statues (Davis 1986). All statistical procedures were carried out with the Statistica software (version 8.0).

\section{Results and discussion}

\section{Macroscopic rock classification and provenance hypotheses}

The rocks of statues MC35, TD590, and TD56356 were found to be essentially different from all others in the studied sample. They are fine-grained, aphanitic rocks with very dense, homogeneous matrices. MC35 is olive black, and TD590 and TD56356 are dark gray. Due to their fine-grained nature, exact grain sizes and mineralogy could not be determined. No visible attraction between the neodymium magnet and these rocks could be observed. This and the other macroscopic characteristics are indicative of greywacke from the Wadi Hammamat in Egypt, the only known ancient quarry for this rock type (Bloxam et al. 2014; Brown and Harrell 1995). The rocks from this location are slightly metamorphosed, compact sedimentary rocks with abundant clay/mica that texturally varies from sandstone (predominant grain size $0.062-2 \mathrm{~mm}$ ) to mudrock $(0.004-0.062 \mathrm{~mm})$. Their colors range from dark gray to nearly black and greenish gray to grayish green (cf. $A E S C$ 28a (a) variety 2 and AESC 28a (a) variety 1, respectively). Pale yellowish brown rounded clasts are visible on the right flank of MC35 (diam. ca. 10 and $3 \mathrm{~cm}$, respectively, i.e., falling within the cobble and pebble size range). Comparable clasts can be observed on several artifacts carved from the Wadi Hammamat greywacke (De Nuccio and Ungaro 2002, 341 no. 41 [P. Liverani]; De Caro 2006, 202 no. III.108 [R. Pirelli]). Based on the strong macroscopic analogies with greywacke from the Wadi Hammamat, the raw materials of statues MC35, TD590, and TD56356 are likely to originate from this Eastern Desert source.

Igneous plutonic origins were determined for all of the remaining fourteen rocks in the sample. Granularity could be observed by the unaided eye in most cases (i.e., these are phaneritic rocks), which means that the average grain size is above $\sim 1 \mathrm{~mm}$. The majority of the statues have well developed textures that are indicative of their plutonic origin. In most cases, the attraction between the studied rocks and the neodymium magnet could be clearly observed. The color indexes, as far as these could be established by visual approximation, range between $\sim 15-25 \%$, and the overall rock colors vary between different shades of gray. This is an indication for the felsic to intermediate compositions of these fourteen rocks. More specifically, the relative abundance of quartz and alkali feldspar relative to biotite and hornblende suggests that the studied granitoid rocks compositionally range from granite to granodiorite. There are, however, several textural and compositional variations among the fourteen statues. Based on this variability, two macroscopic groups with similar appearing stones were recognized, group 1 with nine statues and group 2 with three statues, and another two statues are carved from stones that are dissimilar to all other stones in this study. The latter three stones are referred to as variants 3 and 4 (see Table 1).

Group 1 is the largest group with nine statues. The rocks in this group are dark gray and typically appear as grayish black in polished surfaces. Color indexes are approximately 20 $25 \%$. These rocks are fine to medium grained and have overall fairly homogeneous granular matrices. The finer-grained specimens are largely aphanitic, although some grains can be distinguished with the naked eye, especially on broken surfaces and at a suitable angle to catch the light on cleavage faces. These rocks are therefore medium to mainly fine grained (TD no inv., MC28, MC30, PA362624, PA362622, PA362623). Feldspar phenocrysts are occasionally present and reach up to ca. $5 \mathrm{~mm}$ in the finer-grained specimens and ca. $10 \mathrm{~mm}$ in case of the fine- to mainly medium-grained statues (PA60921, MC31, and PD514563). The dark-colored matrices of seven rocks in this group are crosscut by coarse- to mainly medium-grained, very pale orange to grayish orange pink veins of granitic composition (quartz and alkali feldspar; Fig. 3a). 


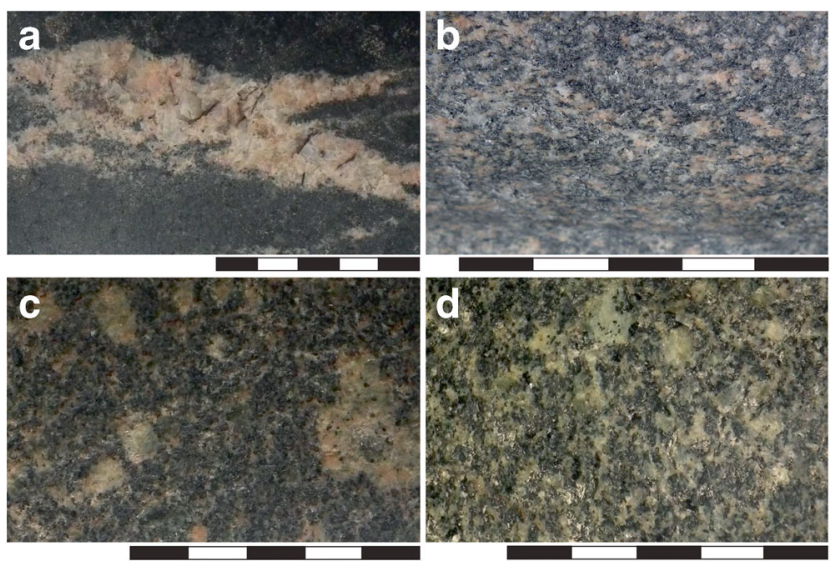

Fig. 3 a-d Macrophotographs of typical facies of studied granitoid rocks. a Group 1. b Group 2. c Variant 3. d Variant 4. Scale in centimeters

The three rocks in group 2 have a lower overall color index $(\mathrm{CI} \approx 15 \%)$ and rock color. These rocks are mainly medium gray to medium light gray, but they grade in parts into medium dark gray to light gray on account of local variations in the concentrations of biotite. They are medium- to mostly fine-grained rocks with fairly equigranular textures, and they show foliation, as evidenced by the parallel arrangement of the feldspar and biotite flakes. These rocks, in other words, have a gneissoid texture (Fig. 3b). Dark-colored patches appear as a streak on front of the base of statue MC32 and as a wavy band on the right shoulder of the baboon. These biotite schlieren, which follow the direction of foliation, are richer in darkcolored biotite than the surrounding rock which accounts for their darker (dark gray to grayish black) color. As opposed to the rocks of group 1 and the two variants described in the following sections, the rocks of group 2 only weakly reacted to the proximity of the neodymium magnet.

The macroscopic characteristics of the rock of the Apis statue (PA182594) are markedly different from the others in the studied sample, and, therefore, this statue is designated to variant 3 (Fig. 3c). The overall rock color is grayish black, and the color index is approximately $20-25 \%$ (hornblende and biotite can be easily observed due to large grain size). It is a coarse- to mainly medium-grained porphyritic rock with abundant anhedral to subhedral plagioclase feldspar phenocrysts up to ca. $30 \mathrm{~mm}$ across, and less frequent alkali feldspar phenocrysts (up to ca. $15 \mathrm{~mm}$ across), several of which exhibit a rapaviki texture. A medium-grained granitic vein cuts across the dark-colored matrix. The rock of the head of a priest (PA112108), finally, is another variety, variant 4 (Fig. 3d). It is an overall mottled dark gray and yellowish gray, mainly medium-grained porphyritic rock with abundant plagioclase feldspar phenocrysts up to ca. $25 \mathrm{~mm}$ across and $\mathrm{CI} \approx 20 \%$ (hornblende and biotite). The mostly anhedral to subhedral phenocrysts show a distinct parallel orientation. This rock is therefore a gneissoid variety of granodiorite.
A preliminary geological study has shown that strong macroscopic analogies exist between the raw materials of the fourteen statues and different granitoids outcropping in the Aswan area (Fig. 4). These rocks exhibit a wide range of compositional and textural variations, including two main varieties of granite and at least three principal types of granodiorite (El-Shazly 1954; Attia 1955; Higazy and Wasfy 1956; Aston et al. 2000; Klemm and Klemm 2008). Among these is a medium- to mainly fine-grained, non-porphyritic granite, also known as Saluja-Sehel Granite (Finger et al. 2008). These rocks vary from red/ pink to gray in color, with the gray variety mainly located at the northeast of the Aswan Dam (Soliman 1980). The biotite flakes, i.e., the dominant dark-colored mineral in these rocks, often show a parallel arrangement (i.e., these are gneissoid granites). The biotite contents moreover may exhibit local variations due to which the overall rock color may vary over small distances (Attia 1955), and biotite schlieren and granitic veins are commonly observed in these rocks (Gindy 1956; Higazy and Wasfy 1956).

The most abundant variety of granodiorite at Aswan is (1) gray in color and spotted with white and pinkish feldspar phenocrysts up to ca. $30 \mathrm{~mm}$ across, which may be parallel aligned. A second, basic variety is (2) dark gray in color, with abundant dark-colored minerals and less welldeveloped feldspar phenocrysts. This includes a finegrained variant with occasional feldspar phenocrysts up to max. ca. $2 \mathrm{~mm}$ across (Middleton and Klemm 2003). The third variety (3) is a gneissose granodiorite, which is often developed at Aswan near the contact with coarsegrained granite (El-Shazly 1954; Attia 1955; Noweir et al. 1990). The presence of pink granitic veins cutting across the dark-colored matrices (De Putter and Karlshausen 1992; Middleton and Klemm 2003) and the rapaviki texture of the feldspar phenocrysts (Higazy and Wasfy 1956; Ragab et al. 1978; Meneisy et al. 1979) are common features in granodiorites from Aswan.

The macroscopic characteristics of the rocks in group 1 closely correspond to the descriptions of granodiorite variety (2) from the literature. The finer-grained specimens in this group show strong similarities to AESC 5(b) variety 1 , samples 1-2. The macroscopic features of the rocks in group 2, next, are fully consistent with published descriptions of the gray Saluja-Sehel Granite (cf. AESC 5 (d) variety 2, sample 1-2). Strong macroscopic analogies exist between granodiorite variant 3 and variety (1) from the literature, and variant (4) is consistent with the description of granodiorite variety (3) (cf. sample 439 in the Klemm Collection: Klemm and Klemm 2008, plate 81). Based on the strong macroscopic similarities between the studied rocks and granitoids from Aswan, it is our hypothesis that the raw materials of all fourteen statues were possibly extracted from the ancient granite-granodiorite quarries at Aswan. 
Fig. 4 Map of Egypt, showing the location of sites mentioned. Names in italics are displayed for reference purposes

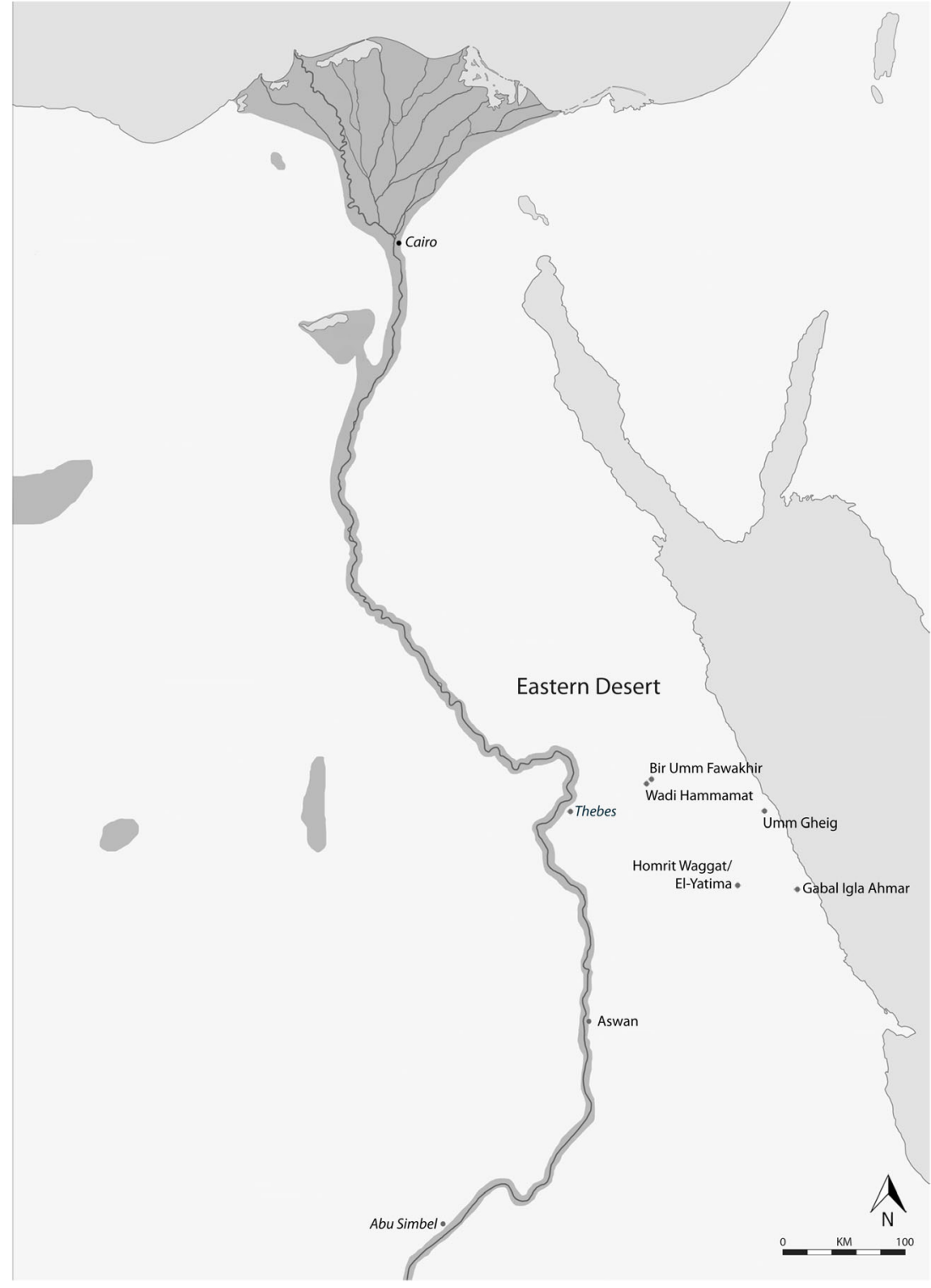

\section{X-ray fluorescence analysis (HH-XRF)}

The chemical compositions of 38 XRF measurements on the seventeen statues are reported in Table 2. Macroscopic analysis has previously suggested that three statues in the studied sample were carved from greywacke (MC35, TD590, TD56356) and the other fourteen from granitoid rocks. To evaluate these observations, a first multivariate analysis of all chemical elements by PCA was conducted to cover and identify potential geochemical variation. A graphical output shows that the first two components cover $\sim 60 \%$ of the variability (Fig. 5). This plot shows, first of all, a clear separation of greywacke from the other studied rocks, which is mainly due to lower values of $\mathrm{Zr}, \mathrm{FeO}$ (total), and $\mathrm{TiO}_{2}$. There is, however, also significant variation detected between the different measurements of the granitoid stones. In order to evaluate if and to what extent this variability corresponds to the potential identification of different groups of granitoid rocks and their varieties on the basis of macroscopic examinations, and to assess the provenance hypotheses formulated previously, in the remainder of the analyses, we will focus only on the compositional variability in granodiorite.

Oxide values of the granitoid measurements are reported in wt.\%, all others in ppm. A brief overview of the analytical output reveals $\mathrm{CaO}$ lower and upper quartile ranges between 2.64 and $4.07 \mathrm{wt} \%$. Only one individual measurement is above $8.0 \mathrm{wt} \%$ (PA182594). The total $\mathrm{FeO}$ content has a rather broad range, from 2.40 to $8.40 \mathrm{wt} \%$ lower and upper quartile. $\mathrm{K}_{2} \mathrm{O}$ is mostly restricted within the 0.9 to $1.87 \mathrm{wt} \%$ range. $\mathrm{TiO}_{2}$ is very variable between the different statues, with samples on the lower end 0.77 and $2.0 \mathrm{wt} \%$ on the high end. Trace element composition is relatively homogeneous with 
Table 2 HH-XRF analyses of sampled sculptures

\begin{tabular}{|c|c|c|c|c|c|c|c|c|c|c|c|c|c|c|}
\hline & Sculpture & Classification & $\begin{array}{l}\mathrm{K}_{2} \mathrm{O} \\
(\mathrm{wt} \%)\end{array}$ & $\begin{array}{l}\mathrm{CaO} \\
(\mathrm{wt} \%)\end{array}$ & $\begin{array}{l}\mathrm{TiO} \\
\text { (wt } \%)\end{array}$ & $\begin{array}{l}\mathrm{Cr} \\
(\mathrm{ppm})\end{array}$ & $\begin{array}{l}\mathrm{MnO} \\
(\mathrm{wt} \%)\end{array}$ & $\begin{array}{l}\mathrm{FeO}(\mathrm{T}) \\
(\mathrm{wt} \%)\end{array}$ & $\begin{array}{l}\mathrm{Ni} \\
(\mathrm{ppm})\end{array}$ & $\begin{array}{l}\mathrm{Zn} \\
(\mathrm{ppm})\end{array}$ & $\begin{array}{l}\mathrm{Sr} \\
(\mathrm{ppm})\end{array}$ & $\begin{array}{l}\mathrm{Zr} \\
(\mathrm{ppm})\end{array}$ & $\begin{array}{l}\mathrm{Nb} \\
(\mathrm{ppm})\end{array}$ & $\begin{array}{l}\mathrm{Ba} \\
(\mathrm{ppm})\end{array}$ \\
\hline$Z$ & & & 19 & 20 & 22 & 24 & 25 & 26 & 28 & 30 & 38 & 40 & 41 & 56 \\
\hline 1 & MC35 & Greywacke & 1.16 & 1.52 & 0.43 & 81 & 0.18 & 4.91 & 66 & 79 & 253 & 126 & 4 & 1481 \\
\hline 2 & TD590 & Greywacke & 0.90 & 2.33 & 0.21 & n.d. & n.d. & 3.94 & 10 & 110 & 202 & 87 & 4 & 1331 \\
\hline 3 & TD56356 & Greywacke & 1.09 & 0.70 & 0.14 & $<10$ & n.d. & 2.81 & 10 & 95 & 176 & 86 & 5 & 893 \\
\hline 4 & TD (no inv.) & GD group 1 & 1.17 & 4.15 & 1.54 & n.d. & n.d. & 8.62 & n.d. & 124 & 276 & 300 & 28 & 1487 \\
\hline 5 & TD (no inv.) & GD group 1 & 0.41 & 6.21 & 0.65 & $<10$ & n.d. & 6.22 & n.d. & 242 & 296 & 331 & 29 & 1565 \\
\hline 6 & TD (no inv.) & GD group 1 & 0.57 & 7.19 & 1.02 & 57 & n.d. & 8.03 & n.d. & 156 & 273 & 286 & 26 & 1193 \\
\hline 7 & MC28 & GD group 1 & 1.90 & 2.69 & 2.37 & n.d. & 0.13 & 10.69 & n.d. & 115 & 299 & 319 & 25 & 1465 \\
\hline 8 & MC28 & GD group 1 & 1.06 & 2.55 & 1.69 & n.d. & 0.19 & 9.10 & n.d. & 180 & 269 & 288 & 21 & 1227 \\
\hline 9 & MC30 & GD group 1 & 2.43 & 3.24 & 2.06 & n.d. & 0.15 & 9.54 & n.d. & 169 & 252 & 267 & 21 & 971 \\
\hline 10 & МC30 & GD group 1 & 1.60 & 2.56 & 2.06 & n.d. & n.d. & 8.28 & $<10$ & 105 & 233 & 238 & 21 & 1058 \\
\hline 11 & PA362624 & GD group 1 & 1.35 & 3.59 & 2.63 & 100 & n.d. & 9.82 & n.d. & 116 & 298 & 282 & 22 & 1214 \\
\hline 12 & PA362624 & GD group 1 & 2.19 & 4.44 & 2.57 & 59 & n.d. & 10.41 & n.d. & 112 & 296 & 303 & 23 & 1194 \\
\hline 13 & PA362624 & GD group 1 & 1.81 & 2.59 & 1.58 & n.d. & n.d. & 7.44 & $<10$ & 107 & 288 & 305 & 16 & 1226 \\
\hline 14 & PA362624 & GD group 1 & 1.48 & 4.66 & 2.19 & 11 & 0.14 & 9.02 & n.d. & 110 & 235 & 299 & 31 & 987 \\
\hline 15 & PA362624 & GD group 1 & 1.17 & 3.81 & 2.08 & n.d. & n.d. & 9.34 & 17 & 105 & 317 & 255 & 22 & 1059 \\
\hline 16 & PA362622 & GD group 1 & 0.41 & 2.97 & 2.08 & n.d. & 0.13 & 7.13 & 16 & 97 & 290 & 261 & 19 & 1245 \\
\hline 17 & PA362622 & GD group 1 & 0.74 & 2.68 & 1.94 & n.d. & n.d. & 6.56 & n.d. & 84 & 248 & 275 & 18 & 948 \\
\hline 18 & PA362622 & GD group 1 & 1.16 & 3.12 & 1.54 & $<10$ & n.d. & 7.34 & n.d. & 97 & 305 & 289 & 17 & 1255 \\
\hline 19 & PA362622 & GD group 1 & 1.08 & 3.45 & 2.01 & n.d. & n.d. & 8.19 & 12 & 99 & 285 & 285 & 21 & 1266 \\
\hline 20 & PA362622 & GD group 1 & 0.86 & 2.62 & 1.08 & n.d. & 0.13 & 6.13 & n.d. & 89 & 245 & 212 & 17 & 859 \\
\hline 21 & PA362622 & GD group 1 & 0.90 & 2.79 & 1.34 & 28 & n.d. & 7.52 & n.d. & 104 & 257 & 281 & 18 & 936 \\
\hline 22 & PA362623 & GD group 1 & 0.81 & 3.78 & 1.68 & 21 & n.d. & 8.09 & n.d. & 108 & 369 & 458 & 21 & 1259 \\
\hline 23 & PA362623 & GD group 1 & 0.49 & 2.76 & 1.45 & n.d. & n.d. & 6.39 & $<10$ & 98 & 269 & 216 & 18 & 709 \\
\hline 24 & PA362623 & GD group 1 & 0.82 & 3.02 & 1.41 & n.d. & 0.12 & 6.81 & n.d. & 89 & 317 & 186 & 16 & 917 \\
\hline 25 & PA60921 & GD group 1 & 1.43 & 3.48 & 1.37 & n.d. & n.d. & 7.58 & n.d. & 114 & 275 & 295 & 28 & 1504 \\
\hline 26 & PA60921 & GD group 1 & 0.90 & 3.43 & 1.12 & n.d. & n.d. & 7.65 & n.d. & 170 & 285 & 307 & 25 & 1390 \\
\hline 27 & MC31 & GD group 1 & 0.93 & 5.88 & 2.59 & n.d. & 0.13 & 8.40 & n.d. & 104 & 351 & 227 & 15 & 933 \\
\hline 28 & PD514563 & GD group 1 & 1.16 & 4.07 & 1.93 & n.d. & n.d. & 7.17 & n.d. & 115 & 356 & 114 & 16 & 1132 \\
\hline 29 & PD514563 & GD group 1 & 1.18 & 3.13 & 1.45 & n.d. & 0.12 & 6.00 & n.d. & 108 & 471 & 124 & 12 & 1166 \\
\hline 30 & MC26 & Granite group 2 & 2.13 & 4.56 & 0.24 & n.d. & 0.04 & 0.89 & $<10$ & 67 & 219 & 230 & 20 & 2479 \\
\hline 31 & MC32 & Granite group 2 & 2.22 & 4.21 & 0.10 & 42 & 0.05 & 3.48 & n.d. & 108 & 203 & 382 & 12 & 2082 \\
\hline 32 & MC2384 & Granite group 2 & 2.04 & 1.33 & 0.04 & n.d. & 0.33 & 1.17 & 11 & 52 & 146 & 336 & 8 & 1579 \\
\hline 33 & PA182594 & GD variant 3 & 2.62 & 2.26 & 0.72 & 30 & n.d. & 4.01 & n.d. & 104 & 297 & 190 & 17 & 1502 \\
\hline 34 & PA182594 & GD variant 3 & 1.44 & 3.87 & 0.99 & 25 & n.d. & 6.20 & $<10$ & 116 & 251 & 342 & 21 & 1344 \\
\hline 35 & PA182594 & GD variant 3 & 1.87 & 3.75 & 0.77 & n.d. & 0.09 & 4.99 & n.d. & 162 & 323 & 251 & 18 & 1664 \\
\hline 36 & PA112108 & GD variant 4 & 1.84 & 2.37 & 0.68 & $<10$ & n.d. & 3.94 & n.d. & 92 & 331 & 55 & 17 & 1407 \\
\hline 37 & PA112108 & GD variant 4 & 1.39 & 2.21 & 0.67 & 42 & 0.10 & 3.83 & n.d. & 93 & 306 & 143 & 17 & 1368 \\
\hline 38 & PA112108 & GD variant 4 & 1.94 & 2.64 & 0.71 & n.d. & n.d. & 4.83 & n.d. & 105 & 320 & 61 & 18 & 1550 \\
\hline
\end{tabular}

n.d. not determined, $G D$ granodiorite

quartile ranges between 252 and $317 \mathrm{ppm}$ (Sr), 216-303 ppm (Zr), 97-116 ppm (Zn), and 1058-1487 ppm (Ba). The measurements of $\mathrm{Cr}$ and $\mathrm{Ni}$ were for the most part not detected or close to the detection limit of the instrument. Given the higher error margins, the results for these two elements are only partial in nature and should not be considered reliable enough for identification purposes.
An important feature is to determine the intra-measurement variability of the various statues through multiple spot analyses, in order to assess the ability to obtain comparable results. This was carried out on flat surfaces and concentrated on the most fine-grained parts of the matrices. The actual observations are also graphically represented in a series of biplots (Fig. 6). In general, intra-statue variability is fairly restricted, 

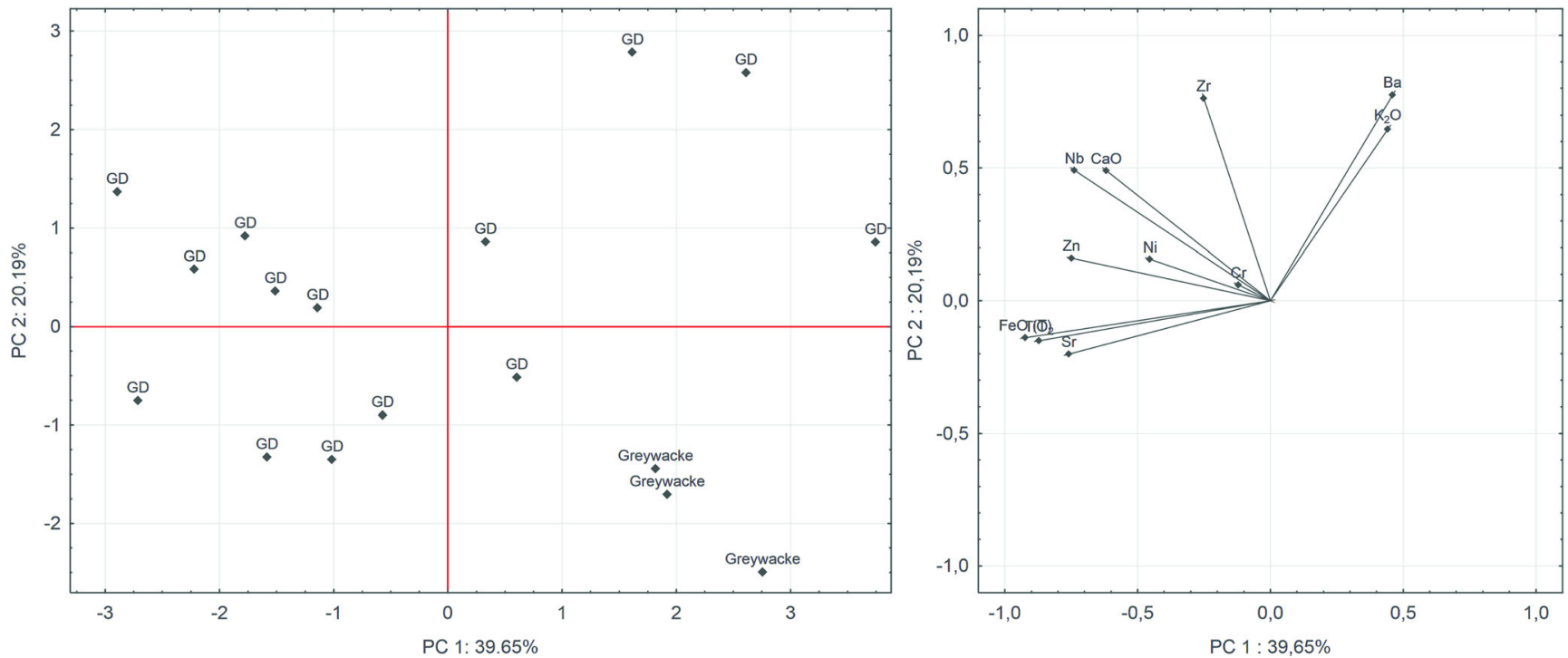

Fig. 5 Principal component analysis of seventeen statues according to rock classification. $G D$ granodiorite

except for some statues where a larger range of values is found, e.g., in PA362622, values for $\mathrm{TiO}_{2}$ range between approx. 1-2 wt\%, and $\mathrm{Sr}$ values range in PD514563 between approx. 350-450 ppm. Although variability remains within these boundaries, a considerable overlap can be identified between most of the statues, especially related to the macroscopic grouping. This relation to the previously identified macroscopic groups is represented in Fig. 7 (see also Table 1). Macroscopic group 1 (granodiorite) comprises fine- and medium-grained material and is shown to have the widest range of chemical values. Nevertheless, these can be clearly and consistently separated from macroscopic groups 2 (granite) and variant 4 by their systematically higher $\mathrm{Ti}, \mathrm{Sr}$, and $\mathrm{Fe}$ values and lower $\mathrm{Ba}$ and $\mathrm{K}$ levels. Variant 3 cannot be clearly discerned chemically from macroscopic groups 1 and variant 4 , yet shows considerable variation opposite to macroscopic group 2.

Principal component analysis was subsequently carried out to determine the influence and variability of all elements on the obtained average values for each statue. As such, interstatue differences can be identified as well as the contributions of each element towards this difference. Overall, the first three principal components cover approximately $85 \%$ of explained variance. A graphical representation of the first two components reports the construction of at least two chemical groups (Fig. 8). Most of the statues of macroscopic group 1 share a common geochemical profile of which some exhibit differences, notably statues MC31 and TD (no inv.). Statues MC2384, MC32, and MC26 form a closely connected second group and are substantially enriched in $\mathrm{K}_{2} \mathrm{O}$ and $\mathrm{Ba}$, which is consistent with the characterization of these rocks as granites. Some statues show variability opposite to macroscopic groups 1 and 2. Statue PA112108 (macroscopic variant 4), for example, shows more depleted levels of $\mathrm{Zr}$ in the matrix opposite to other statues. The Apis statue (PA182594, macroscopic variant 3 ) indicates a better chemical consistency to the main group 1. Statue PD514563, lastly, seems significantly more enriched in $\mathrm{CaO}$ and $\mathrm{Sr}$, suggesting another potential different chemical variation.

When evaluating the elements contributing to the overall variability, a close overlap can be seen in $\mathrm{K}_{2} \mathrm{O}$ and $\mathrm{Ba}$, likely relating to a feldspar component, $\mathrm{CaO}-\mathrm{Sr}$, common for
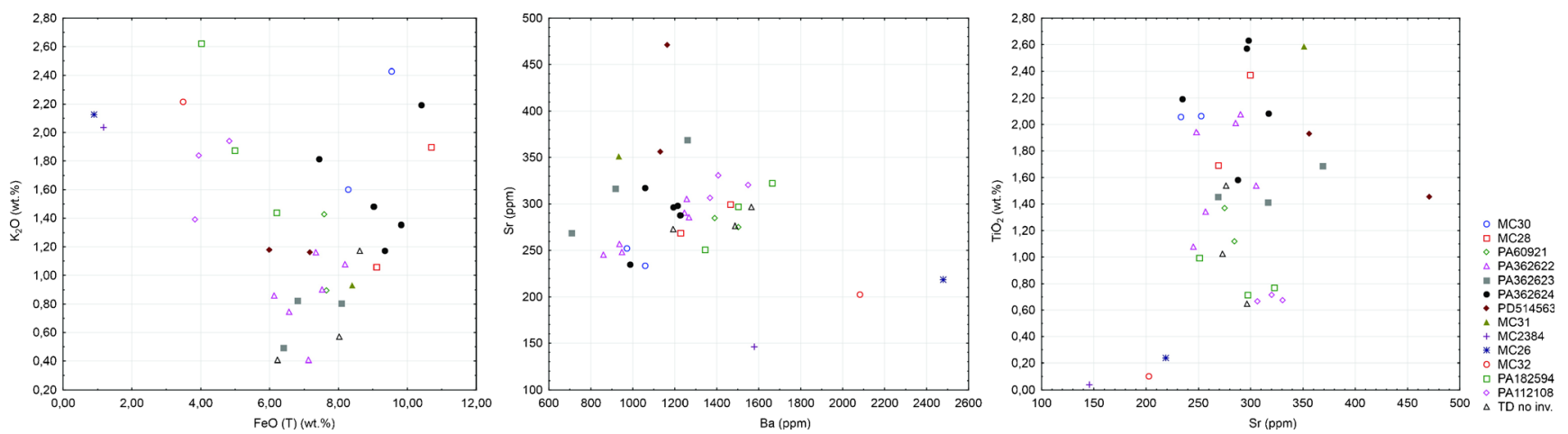

Fig. 6 Bivariate plots of individual measurements grouped per statue 

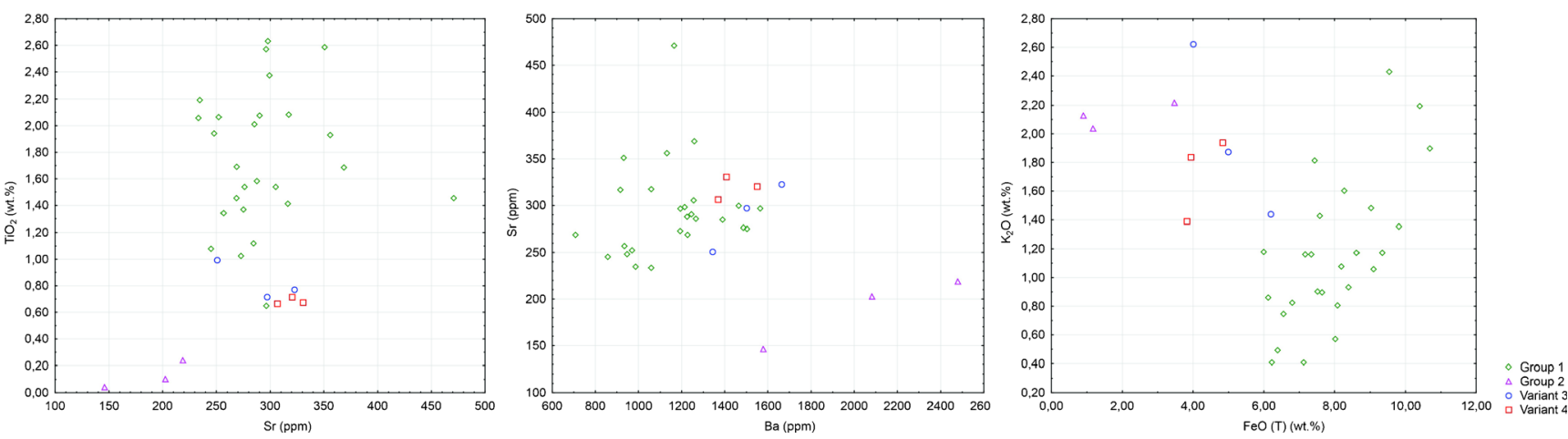

Fig. 7 Bivariate plots of individual measurements grouped per macroscopic group

carbonate phases, and $\mathrm{FeO}-\mathrm{TiO}_{2}$, representing a heavy mineral fraction. Other elements, such as $\mathrm{Zr}$, do not seem to correlate with any other elements.

Results obtained from both the bivariate plots and statistical analyses show a consistent pattern. It can be concluded that the granodiorites (group 1) and granites (group 2) provide two consistent chemical groupings, which signify a clearly different measured chemical composition of the granitoid microstructure. Apart from both these macrogroups, the individual samples (PA182594, PA112108, PD514563) show variability that cannot be directly attributed to either of these two groups. A clear correspondence is thus obtained between both the macroscopic and the chemical approach apart from the previously defined differentiation in chemical values for these three statues. This demonstrates the potential of discrimination on a group level when focusing on fine-grained matrices through multiple spot analysis. Based on these results, it can be concluded that HH-XRF can be a useful additional technique in exploring chemical differences for compositional studies of granitoid rocks, although with a more limited resolution of differentiation than invasive laboratory techniques like ICPMS and NAA (Pollard et al. 2007). Laser ablation systems coupled to ICP-MS could be an alternative on a microinvasive scale (Dussubieux et al. 2016), but still these techniques require a small sample which may be difficult to obtain, as in the case of the sculptures studied in this paper. Next, in order to assess the potential of this technique for the determination of an Aswan provenance and to evaluate macroscopic hypotheses, the chemical results will be compared to a dataset of published results from Egyptian granitoid rocks.

\section{Discussion of provenance hypotheses}

In order to evaluate the hypothesis that the raw materials of the fourteen studied granitoid statues were extracted from the granite-granodiorite quarries at Aswan, we compared the results of our analyses to previously published whole-rock analyses of granites and granodiorites from Aswan, as well as several sources of granodiorite in the Eastern Desert. Aswan granodiorites can be distinguished from stones with similar compositions from the Eastern Desert on the basis of notable differences in $\mathrm{Fe}$, $\mathrm{Ti}, \mathrm{Ca}$, and $\mathrm{K}$ contents. Relative to granodiorites from the Eastern Desert, Aswan granodiorites are significantly enriched in total $\mathrm{Fe}$ and Ti contents $(\sim 8.0 \mathrm{wt} \% \mathrm{FeO}$, $\sim 2.50 \mathrm{wt} \% \mathrm{TiO}_{2}$ for Aswan and $3.5 \mathrm{wt} \% \mathrm{FeO}, \sim 0.50 \mathrm{wt} \%$ $\mathrm{TiO}_{2}$ for average Eastern Desert values) and relatively
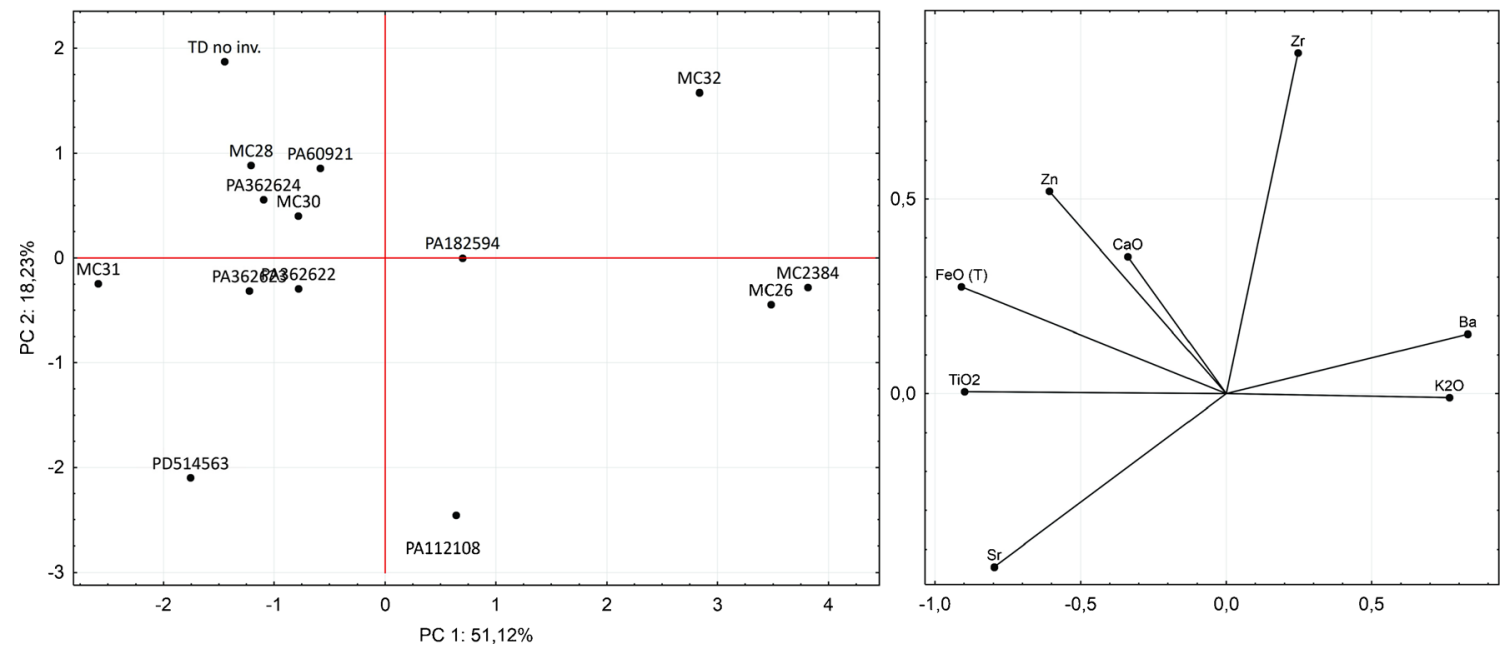

Fig. 8 Graphical distribution of extracted principal component 1 and 2 loadings in combination with the PC1 and PC2 scores 
depleted in $\mathrm{Ca}$ and $\mathrm{K}$ contents. A ternary plot showing the relative Ti-Fe-K elemental composition of the sampled statues demonstrates that most of the granodiorites are relatively consistent with data from the Aswan area and different from Eastern Desert sources (Fig. 9, values are reported in Table 3; for the mentioned sites, see Fig. 4). This close chemical consistency suggests that the raw materials for these statues were indeed obtained from the quarries at Aswan.

A minority of the sculptures in this study show a different pattern. Statues MC26, MC32, and MC2384 were found to be different from the granodiorite group, which corresponds well with the macroscopic characterization of these rocks as granite. These statues are chemically characterized by notably low concentrations of $\mathrm{FeO}$ and $\mathrm{TiO}_{2}$ that are not consistent with the known granodiorites from Aswan. The ternary plot in Fig. 9 shows that these rocks have a chemical composition that better matches the published data of granodiorites from the Eastern Desert and those of the Aswan fine-grained and (monzo)granites (e.g., lower $\mathrm{TiO}_{2}$, higher $\mathrm{K}_{2} \mathrm{O}$ ) under the current analytical setup.

Of the granodiorite sources in the Eastern Desert plotted in Fig. 9, Bir Umm Fawakhir is the only one that was anciently quarried. It is, however, highly unlikely that this source provided the raw materials for the statues of group 2: MC26, MC32, and MC2384. Not only are there macroscopic differences between the rocks of these three statues and the stones from the Bir Umm Fawakhir quarries, particularly in terms of mineralogy, color, and texture, but also the quarries at Bir Umm Fawakhir were exclusively worked during the first and second centuries $\mathrm{AD}$ and only for the production of architectural elements such as columns and pavement tiles (Brown and Harrell 1995; Lazzarini 2002; for a color photograph of a representative slab from Bir Umm Fawakhir, see AESC 27, sample 1). The fact that the relevant objects are sculptures that were carved long before the extraction at the Fawakhir quarries began eliminates these quarries as likely a source area. It is therefore highly likely that these three statues are indeed carved from granite, and not granodiorite, as the preliminary macroscopic analysis has suggested. The chemical correspondence to the fine-grained granite from Aswan, i.e., low concentrations of $\mathrm{FeO}$ and $\mathrm{TiO}_{2}$ and high $\mathrm{K}_{2} \mathrm{O}$ and $\mathrm{CaO}$ values, suggest that like the studied granodiorites also the fine-grained granites of macrogroup 2 were obtained from the quarries at Aswan.

\section{Conclusions}

This paper represents the first exploration of a fully nondestructive characterization of Egyptian statues from Imperial Rome. The results presented here show that careful macroscopic and chemical observations provide a clear discrimination between commonly confused stone types like greywacke, gray granite, and granodiorite. Combining a macroscopic approach with in situ HH-XRF analysis demonstrates the potential to identify granitoid rocks and their variants, although restrictions on resolution and details of analysis apply. Three main issues were addressed in this paper: (1) the relation between macroscopic and chemical analyses, (2) potential and resolution of HH-XRF for identification of
Fig. 9 Ternary diagram of samples in this study (group 1granodiorites: green diamonds; group 2 -fine-grained granites: red diamonds; variant 3-yellow diamond; variant 4-black diamond) compared to existing literature data of Aswan granitoid rocks: granodiorite (blue squares), tonalite (purple squares), monzogranite (orange squares), coarse granite (black squares), and fine granite (green squares). Granodiorites from the Eastern Desert and a global average composition of granodiorite are indicated in red circles and a yellow square, respectively. All values are reported in Table 3

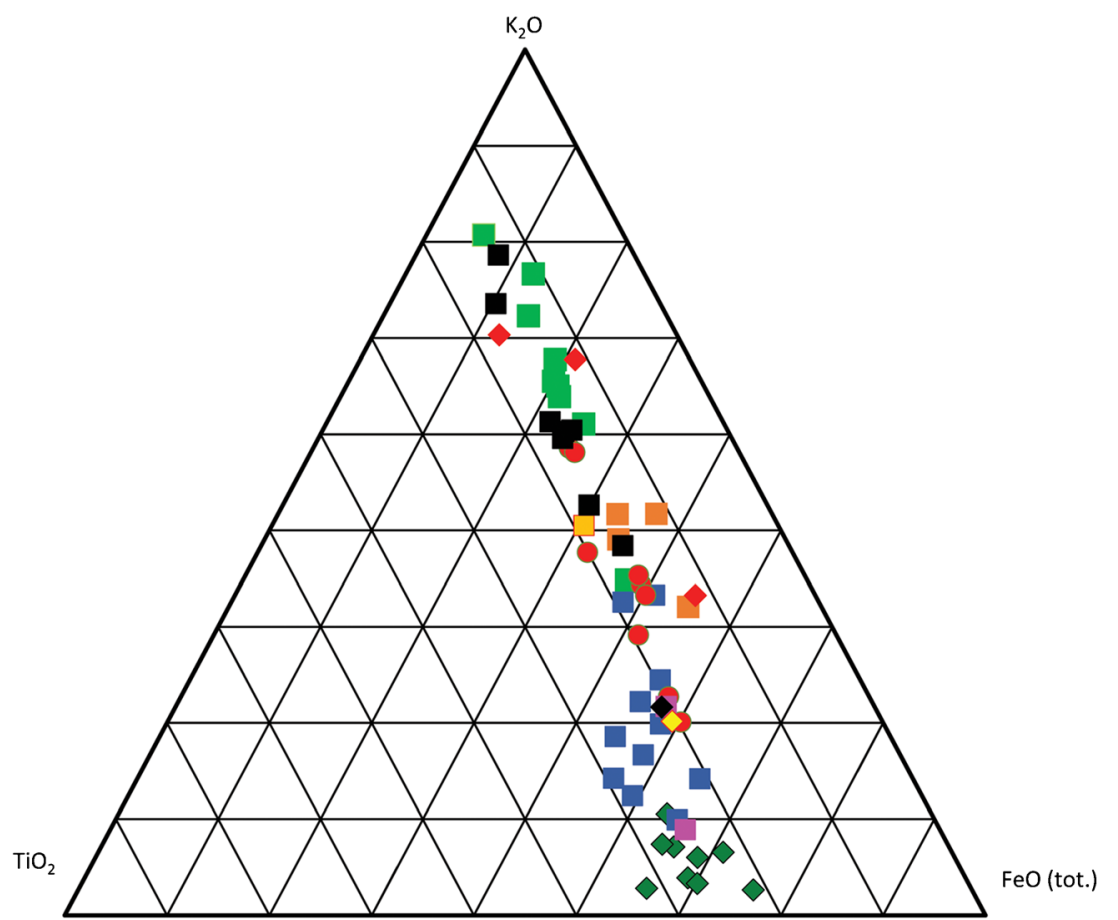


Table 3 Comparison of granitoid compositions from the present study and the literature

\begin{tabular}{|c|c|c|c|c|c|}
\hline Sculptures (this study) & $\begin{array}{l}\mathrm{CaO} \\
(\mathrm{wt} \%)\end{array}$ & $\begin{array}{l}\mathrm{K}_{2} \mathrm{O} \\
(\mathrm{wt} \%)\end{array}$ & $\begin{array}{l}\mathrm{TiO}_{2} \\
(\mathrm{wt} \%)\end{array}$ & $\begin{array}{l}\mathrm{FeO}(\mathrm{T}) \\
(\mathrm{wt} \%)\end{array}$ & Macrogroup \\
\hline TD no inv. & 5.85 & 0.72 & 1.07 & 7.62 & 1 \\
\hline MC28 & 2.62 & 1.48 & 2.03 & 9.90 & 1 \\
\hline MC30 & 2.90 & 2.02 & 2.06 & 8.91 & 1 \\
\hline PA362624 & 3.81 & 1.53 & 2.13 & 8.95 & 1 \\
\hline PA362622 & 2.94 & 0.86 & 1.66 & 7.15 & 1 \\
\hline PA362623 & 3.20 & 0.83 & 1.65 & 7.51 & 1 \\
\hline PA60921 & 3.45 & 1.16 & 1.24 & 7.62 & 1 \\
\hline MC31 & 5.88 & 0.93 & 2.59 & 8.40 & 1 \\
\hline PD514563 & 3.60 & 1.17 & 1.69 & 6.58 & 1 \\
\hline MC26 & 4.56 & 2.13 & 0.24 & 0.89 & 2 \\
\hline MC32 & 4.21 & 2.22 & 0.10 & 3.48 & 2 \\
\hline MC3284 & 1.33 & 2.04 & 0.04 & 1.17 & 2 \\
\hline PA182594 & 3.29 & 1.98 & 0.83 & 5.06 & Variant 3 \\
\hline PA112108 & 2.62 & 1.82 & 0.74 & 4.27 & Variant 4 \\
\hline Literature values & $\mathrm{CaO}(\mathrm{wt} \%)$ & $\mathrm{K}_{2} \mathrm{O}(\mathrm{wt} \%)$ & $\mathrm{TiO}_{2}(\mathrm{wt} \%)$ & $\begin{array}{r}\mathrm{FeO}(\mathrm{T}) \\
(\mathrm{wt} \%)\end{array}$ & \\
\hline \multicolumn{6}{|l|}{ Aswan—granodiorite } \\
\hline $\begin{array}{l}\text { Higazy and Wasfy (1956) } \\
\quad(n=3)\end{array}$ & $4.55 \pm 1.04$ & $3.35 \pm 0.75$ & $1.70 \pm 0.60$ & $8.67 \pm 2.21$ & - \\
\hline $\begin{array}{l}\text { Meneisy et al. (1979) } \\
\quad(n=5)\end{array}$ & $4.45 \pm 0.67$ & $3.07 \pm 0.36$ & $1.92 \pm 0.52$ & $8.03 \pm 0.74$ & - \\
\hline $\begin{array}{l}\text { Middleton and Klemm (2003) } \\
\text { Rosetta Stone (avg. three } \\
\text { analyses) }\end{array}$ & 4.00 & 2.30 & 1.30 & 8.40 & - \\
\hline $\begin{array}{l}\text { Middleton and Klemm (2003) } \\
489 \text { (avg. two analyses) }\end{array}$ & 4.20 & 2.50 & 2.50 & 8.00 & - \\
\hline $\begin{array}{l}\text { Noweir et al. (1990) 200-201 } \\
(n=2)\end{array}$ & $2.82 \pm 0.29$ & $3.57 \pm 0.65$ & $0.53 \pm 0.13$ & $5.21 \pm 0.73$ & - \\
\hline \multicolumn{6}{|l|}{ Aswan-tonalite } \\
\hline Finger et al. (2008) D1 & 5.81 & 1.97 & 2.11 & 10.09 & - \\
\hline Finger et al. (2008) D3 & 4.00 & 3.17 & 1.23 & 7.47 & - \\
\hline \multicolumn{6}{|l|}{ Aswan - fine-grained granite } \\
\hline Finger et al. (2008) Fg2 & 1.05 & 5.14 & 0.25 & 1.40 & - \\
\hline $\begin{array}{l}\text { Meneisy et al. (1979) } \\
\quad(n=6)\end{array}$ & $1.56 \pm 0.31$ & $5.16 \pm 0.22$ & $0.34 \pm 0.04$ & $3.00 \pm 0.45$ & - \\
\hline $\begin{array}{l}\text { Higazy and Wasfy (1956) C } \\
\text { (grayish pink sample) }\end{array}$ & 2.53 & 4.17 & 0.80 & 5.50 & - \\
\hline $\begin{array}{l}\text { Higazy and Wasfy (1956) D } \\
\text { (red sample) }\end{array}$ & 1.20 & 7.55 & 0.09 & 2.90 & - \\
\hline \multicolumn{6}{|l|}{ Aswan (coarse-grained) - granite } \\
\hline El-Gaby (1975) no. 35 & 2.13 & 4.23 & 0.66 & 3.99 & - \\
\hline Finger et al. (2008) $(n=2)$ & $1.98 \pm 0.28$ & $4.83 \pm 0.08$ & $0.56 \pm 0.04$ & $3.26 \pm 0.06$ & - \\
\hline $\begin{array}{l}\text { Higazy and Wasfy (1956) } \\
(n=2)\end{array}$ & $1.87 \pm 0.57$ & $5.65 \pm 1.06$ & $0.43 \pm 0.13$ & $2.69 \pm 0.59$ & - \\
\hline $\begin{array}{l}\text { Meneisy et al. (1979) 6-19 } \\
\quad(n=13)\end{array}$ & $1.58 \pm 0.22$ & $5.34 \pm 0.59$ & $0.50 \pm 0.08$ & $3.79 \pm 0.57$ & - \\
\hline \multicolumn{6}{|l|}{ Aswan—monzogranite } \\
\hline Noweir et al. (1990) $(n=5)$ & $2.57 \pm 0.27$ & $4.02 \pm 0.61$ & $0.38 \pm 0.23$ & $4.50 \pm 0.77$ & - \\
\hline \multicolumn{6}{|l|}{ Eastern Desert—granodiorite } \\
\hline $\begin{array}{l}\text { Bir Umm Fawakhir } \\
\text { (Brown and Harrell 1995) }\end{array}$ & 2.16 & 3.45 & 0.41 & $2.58^{\mathrm{a}}$ & - \\
\hline $\begin{array}{l}\text { Gabal Igla Ahmar (Hassanen } \\
\text { et al. 1996) }(n=2)\end{array}$ & $3.50 \pm 0.03$ & $2.66 \pm 0.32$ & $0.52 \pm 0.03$ & $3.35 \pm 0.76$ & - \\
\hline $\begin{array}{l}\text { Homrit Waggat/El-Yatima area } \\
1 \text { (Moghazi et al. 1999) } \\
(n=4)\end{array}$ & $3.81 \pm 0.87$ & $2.07 \pm 0.33$ & $0.55 \pm 0.16$ & $3.56 \pm 1.05$ & - \\
\hline $\begin{array}{l}\text { Umm-Gheig (El-Sayed et al. } \\
\text { 2002) }(n=2)\end{array}$ & $3.90 \pm 0.13$ & $2.8 \pm 0.23$ & $0.46 \pm 0.02$ & $3.86 \pm 0.16$ & - \\
\hline $\begin{array}{l}\text { Granodiorite (global average) } \\
\text { (Cox et al. 1979) }\end{array}$ & 3.83 & 2.73 & 0.54 & 2.73 & - \\
\hline
\end{tabular}

Literature values are given as mean value and standard deviation when applicable

n.d. not detected

${ }^{\text {a }}$ Only $\mathrm{Fe}_{2} \mathrm{O}_{3}$ given 
granitoid rocks, and (3) determining an Egyptian (Aswan) origin for the studied raw materials. Our conclusions are as follows:

1. Results from both methods overlap quite significantly and support the obtained grouping and separation between granite and granodiorite. While macroscopic data generally focuses on the visible macrostructure of rocks, $\mathrm{HH}$ $\mathrm{XRF}$ is able to determine the chemical composition of a chosen part of this structure. In this paper, we explored the potential to measure the composition of the dark-colored component. Two main groups and two individual variants were discerned on the basis of macroscopic observations, while another variant was recognized on the basis of the chemical data (statue PD514563). Variants 3 and 4 show considerable differentiation in chemical features in comparison to group 2 (granites). These variants appear to be variations of granodiorite.

2. HH-XRF is a suitable non-destructive technique to explore chemical variations in granitoid rocks, bearing in mind element restrictions and ideally closely connected to macroscopic observations. The adopted approach has shown that granodiorite, granite, and greywacke can be clearly distinguished on the basis of non-destructive compositional analysis. Additionally, analysis of the studied granitoid statues has provided coefficients of variation between multiple spot measurements that are systematic at approximately $\sim 10 \%$. Within these margins, consistent results were obtained which allowed the relative discrimination between groups of different granitoid rocks and their variations. While these margins indicate that obtained results should be considered only as indicative when applied for direct provenancing and comparison, the results nevertheless demonstrate that granitoid materials can be discriminated using HH-XRF when fine-grained matrices are selected for analysis. This technique therefore has an explorative grouping potential that needs further consideration, in particular, because it may help address existing uncertainties over the identification of different rock types and their variations. Additionally, it holds potential to assess questions pertaining to the differentiation of the numerous transitional varieties between granitoid rocks that have been reported at the quarries of Aswan (El-Shazly 1954; Attia 1955; Higazy and Wasfy 1956) and to explore the extent to which and to establish the periods during which these different varieties of Aswan rocks were used for the production of sculpture. In order to assess the full potential of the tracing capabilities of HH-XRF methodology, however, additional geochemical data needs to be collected.

3. The results of the geochemical analyses were compared with published data for granitoids from Aswan and several granodiorites from the Eastern Desert. Aswan emerged as most likely source for the studied rocks on the basis of consistent macroscopic and chemical observations. A connection to the exploitation of other outcrops outside of Aswan is highly unlikely.

Acknowledgements This study was carried out in the context of the $\mathrm{PhD}$-research by S. Müskens at Leiden University within the context of the Nederlandse Organisatie voor Wetenschappelijk Onderzoek VIDI project "Cultural Innovation in a Globalising Society: Egypt in the Roman World" under direction of Prof. M.J. Versluys (2010-2015). The authors wish to thank Dr. C. Parisi-Presicce (Musei Capitolini), Dr. M. De Angelis d'Ossat (Palazzo Altemps), Dr. R. Friggeri (Terme di Diocleziano), and Dr. R. Egidi (Foro Romano e Palatino) for the permission to sample the selected statues and to publish the results. Sincere thanks are also due to Prof. J.A. Harrell (The University of Toledo, Ohio) and Dr. E.R. O'Connell (Department of Ancient Egypt and Sudan, The British Museum, London) for providing the opportunity to study the Ancient Egyptian Stone Collection and the Klemm Collection, respectively; to Dr. S. Trevisan, Dr. S. Violante, and Dr. M. D'Ambrosio for assistance with the sampling of the statues; and to Mrs. I. Bolognese, secretary of the Koninklijk Nederlands Instituut Rome, for facilitating access to the various museums. This paper much benefited from comments on an earlier draft by Prof. J.A. Harrell. Thanks are also due to Bruce Kaiser for all assistance regarding the use of the HH-XRF equipment in Rome.

Open Access This article is distributed under the terms of the Creative Commons Attribution 4.0 International License (http:// creativecommons.org/licenses/by/4.0/), which permits unrestricted use, distribution, and reproduction in any medium, provided you give appropriate credit to the original author(s) and the source, provide a link to the Creative Commons license, and indicate if changes were made.

\section{References}

Abzalov M (2008) Quality control of assay data: a review of procedures for measuring and monitoring precision and accuracy. Explor Min Geol 17:131-144

Arslan EA (ed) (1997) Iside. Il mito - il mistero - la magia. Electa, Milan

Aston B, Harrell J, Shaw I (2000) Stone. In: Nicholson PT, Shaw I (eds) Ancient Egyptian materials and technology. Cambridge University Press, Cambridge, pp. 5-77

Attia MI (1955) Topography, geology and iron-ore deposits of the district east of Aswan. Éditions universitaires d'Égypte, Cairo

Barbera G, Barone G, Crupi V, Longo F, Majolino D, Mazzoleni P, Venuti V (2013) Nondestructive analyses of carbonate rocks: applications and potentiality for museum materials. X-Ray Spectrom 42:8-15

Barone G, Crupi V, Longo F, Majolino D, Mazzoleni P, Spagnolo G, Venuti V, Aquilia E (2011) Potentiality of non-destructive XRF analysis for the determination of Corinthian B amphorae provenance. X-Ray Spectrom 40:333-337

Bloxam E, Harrell J, Kelany A, Moloney N, El-Senussi A, Tohamey A (2014) Investigating the Predynastic origins of greywacke working in the Wadi Hammamat. Archéo-Nil 24:11-30

Bosticco S (1952) Musei Capitolini. I monumenti egizi ed egittizzanti, Cataloghi dei musei comunali di Roma 3. Istituto grafico tiberino, Roma

Bourne JH (1993) Use of magnetic susceptibility, density, and modal mineral data as a guide to the composition of granitic plutons. Math Geol 25:357-375 
Brown VM, Harrell JA (1991) Megascopic classification of rocks. J Geol Educ 39:379-387

Brown VM, Harrell JA (1995) Topographical and petrological survey of ancient Roman quarries in the Eastern Desert of Egypt. In: Maniatis Y, Herz N, Basiakos Y (eds) The study of marble and other stones used in antiquity. ASMOSIA III Athens: transaction0s of the 3rd International Symposium of the Association for the Study of Marble and Other Stones used in Antiquity, held in Athens 17-19 May, 1993. Archetype, London, pp 221-234

Brown VM, Harrell JA (1998) Aswan granite and granodiorite. Göttinger Miszellen 164:33-39

Brysbaert A (2007) Cross-craft and cross-cultural interactions during the Aegean and Eastern Mediterranean Late Bronze Age. In: Antoniadou S, Pace A (eds) Mediterranean crossroads. Pierides Foundation, Athens, pp. 325-359

Bülow Clausen K (2014) The Flavian Isea in Beneventum and Rome. The appropriation of Egyptian and Egyptianising Art in imperial Beneventum and Rome. Unpublished PhD-diss. University of Copenhagen

Candilio D et al. (2011) Palazzo Altemps. Le collezioni. Electa, Milan

Clark DA, Emerson DW (1991) Notes on rock magnetisation characteristics in applied geophysical studies. Explor Geophys 22:547-555

Cox KG, Bell JD, Pankhurst RJ (1979) The interpretation of igneous rocks. G. Allen \& Unwin, London

Davis JC (1986) Statistics and data analysis in geology, 2nd edn. Wiley, New York

De Caro S (ed) (2006) Egittomania. Iside e il mistero. Electa, Milan

De Nuccio M, Ungaro L (eds) (2002) I marmi colorati della Roma imperiale. Marsilio, Venezia

De Putter T, Karlshausen Ch (1992) Les pierres utilisées dans la sculpture et l'architecture de l'Égypte pharaonique, Guide pratique illustrée. Connaissance de l'Egypte ancienne, Brussels

Degryse P, Shortland AJ (2013) Nourishing archaeology and science. P Natl Acad Sci USA 110:20352-20353

Dussubieux L, Golitko M, Gratuze B (2016) Recent advances in laser ablation ICP-MS for archaeology, natural science in archaeology. Springer, Berlin

El-Gaby S (1975) Petrochemistry and geochemistry of some granites from Egypt. Neues Jb Miner Abh 124:147-189

El-Sayed MM, Mohamed FH, Furnes H, Kanisawa S (2002) Geochemistry and petrogenesis of the Neoproterozoic granitoids in the Central Eastern Desert, Egypt. Chem Erde-Geochem 62:317346

El-Shazly EM (1954) Rocks of Aswan area. Government Press, Cairo

Fernandes R, Van Os BJH, Huisman HDJ (2013) The use of handheld $\mathrm{XRF}$ for investigation the composition and corrosion of Roman copper-alloyed artefacts. Heritage Science 1:30

Finger F, Dörr W, Gerdes A, Gharib M, Dawoud M (2008) U-Pb zircon ages and geochemical data for the Monumental Granite and other granitoid rocks from Aswan, Egypt: implications for the geological evolution of the western margin of the Arabian Nubian Shield. Miner Petrol 93:153-183

Frahm E (2014) Characterizing obsidian sources with portable XRF: accuracy, reproducibility, and field relationships in a case study from Armenia. J Archaeol Sci 49:105-125

Gindy AR (1956) Biotite schlieren in some intrusive granites from Egypt and Donegal and their origin. Bulletin de l'Institut du Desert d'Égypte 6:143-157

Glascock MD, Knuselman R, Wolfman D (1999) Intrasource chemical differentiation of Obsidian in the Jemez Mountains and Taos Plateau, New Mexico. J Archaeol Sci 26:861-868

Goren Y, Mommsen H, Klinger J (2011) Non-destructive provenance study of Cuneiform tablets using portable X-ray fluorescence. J Archaeol Sci 38:684-696
Hassanen MA, El-Nisr SA, Mohamed FH (1996) Geochemistry and petrogenesis of pan-African I-type granitoids at Gabal Igla Ahmar, Eastern Desert, Egypt. J Afr Earth Sci 22:29-42

Hernant K (2003) Modelling and interpretation of global lithospheric magnetic anomalies. Unpublished $\mathrm{PhD}$-diss. Freie Universität Berlin 2003

Herz N, Garrison EG (1998) Geological methods for archaeology. Oxford University Press, New York

Higazy RA, Wasfy HM (1956) Petrogenesis of granitic rocks in the neighborhood of Aswan, Egypt. Bulletin de l'Institut du Desert d'Égypte 6:209-256

Hollenback KL, Schiffer MB (2010) Technology and material life. In: Beaudry MC, Hicks D (eds) The Oxford handbook of material culture studies. Oxford University Press, Oxford, pp. 313-332

Hunt CP, Moskowitz BM, Banerjee SK (1995) Magnetic properties of rocks and minerals. In: Ahrens TJ (ed) Rock physics \& phase relations: a handbook of physical constants, AGU Reference Shelf 3. American Geophysical Union, Washington DC, pp. 189-204

Hunt AMW, Speakman RJ (2015) Portable XRF analysis of archaeological sediments and ceramics. J Archaeol Sci 53:626-638

Jones AM, Boivin N (2010) The malice of inanimate objects: material agency. In: Beaudry MC, Hicks D (eds) The Oxford handbook of material culture studies. Oxford University Press, Oxford, pp. 333351

Kempe DRC, Harvey AP (eds) (1983) The petrology of archaeological artefacts. Clarendon Press, Oxford

Klemm DD, Klemm R (2001) The building stones of ancient Egypt - a gift of its geology. J Afr Earth Sci 22:631-642

Klemm R, Klemm DD (2008) Stones and quarries in ancient Egypt. British Museum Press, London

La Rocca E, Parisi Presicce C (eds) (2010) Musei Capitolini. Le sculture del Palazzo Nuovo I. Electa, Milan

Lazzarini L (2002) La determinazione della provenienza delle pietre decorative usate dai Romani. In: De Nuccio M, Ungaro L (eds) I marmi colorati della Roma imperiale. Marsilio, Venezia, pp. 223-265

Lembke K (1994) Das Iseum Campense in Rom. Studie über den Isiskult unter Domitian, Archäologie und Geschichte 3. Verlag Archäologie und Geschichte, Heidelberg

Le Maitre RW, Streckeisen A, Zanettin B, Le Bas MJ, Bonin B, Bateman P, Bellieni G, Dudek A, Efremova S, Keller J, Lameyre J, Sabine PA, Schmid R, Sørensen H, Woolley AR (2002) Igneous rocks. A classification and glossary of terms. Recommendations of the International Union of Geological Sciences Subcommission on the Systematics of Igneous Rocks, 2nd edn. Cambridge University Press, Cambridge

Malaise M (1972) Inventaire préliminaire des documents Égyptiens découverts en Italie, Études préliminaires aux religions orientales dans l'Empire romain 21. Brill, Leiden

Malaise M (2005) Pour une terminologie et une analyse des cultes isiaques, Mémoire de la Classe des Lettres 35. Académie Royale de Belgique, Brussels

Manera F, Mazza C (2001) Le collezioni egizie del Museo Nazionale Romano. Electa, Milan

Meneisy MY, Ragab AI, Taher RM (1979) Contributions to the petrography, petrochemistry and classification of Aswan granitic rocks, Egypt. Chem Erde-Geochem 38:121-135

Middleton A, Klemm D (2003) The geology of the Rosetta stone. J Egypt Archaeol 89:207-216

Moghazi AM, Mohamed FH, Kanisawa S (1999) Geochemical and petrological evidence of calc-alkaline and A-type magmatism in the Homrit Waggat and El-Yatima areas of eastern Egypt. J Afr Earth Sci 29:535-549

Müskens S (2014a) A new fragment of an architectonic Hathor-support from Rome: Aegyptiaca Romana reconsidered. In: Bricault L, Veymiers R (eds) Bibliotheca Isiaca 3. Ausonius Éditions, Bordeaux, pp. 95-116 
Müskens S (2014b) De leeuwen op de trappen naar het Capitool—Egypte in steen. Roma Æterna 2.II: 46-53

Müskens S (2017) Aegyptiaca beyond representation. Materials and materiality of Aegyptiaca Romana, Archaeological Studies Leiden University 35. Leiden University Press, Leiden

Neff H, Voorhies B, Paredas Umana F (2012) Handheld XRF elemental analysis of archaeological sediments: some examples from Mesoamerica. In: Shugar AN, Mass JL (eds) Handheld XRF for art and archaeology, studies in archaeological sciences 3. Leuven University press, Leuven, pp. 379-400

Noweir AM, Abu El Ela AM, Sewifi BM (1990) New contributions to the geology, geochemistry and tectonic settings of the Aswan granites, southern Egypt. Qatar University Science Bulletin 10:395-410

Palumbo S, Golitko M, Christensen S, Tietzer G (2015) Basalt source characterization in the highlands of western panama using portable $\mathrm{X}$-ray fluorescence (pXRF) analysis. J Archaeol Sci 2:61-68

Pollard AM, Batt CM, Stern B, SMM Y (2007) Analytical chemistry in archaeology, Cambridge manuals in archaeology. Cambridge University Press, Cambridge

Quack JF (2003) Zum ägyptischen Ritual im Iseum Campense in Rom. In: Metzner-Nebelsick C (ed) Rituale in der Vorgeschichte, Antike und Gegenwart: Studien zur Vorderasiatischen, Prähistorischen und Klassischen Archäologie, Ägyptologie, Alten Geschichte, Theologie und Religionswissenschaft. Interdisziplinäre Tagung vom 1.-2. Februar 2002 an der Freien Universität Berlin, Internationale Archäologie 4. Verlag M. Leidorf, Rahden, pp 57-66

Ragab AI, Meneisy MY, Taher RM (1978) Contributions to the petrogenesis and age of Aswan granitic rocks, Egypt. Neues Jb Miner Abh 133:71-87

Roullet A (1972) The Egyptian and Egyptianizing monuments of Imperial Rome, Études préliminaires aux religions orientales dans l'Empire romain 20. Brill, Leiden

Scott R, Braekmans D, Brems D, Degryse P (2014) Danger! High voltage! The application of HH-XRF on various archaeological materials. Potentials and pitfalls. In: Scott R, Braekmans D, Carremans M, Degryse P (eds) Proceedings of the 39th International
Symposium on Archaeometry, 28 may-1st June 2012, Leuven, Belgium. Center for Archaeological Sciences, Leuven, pp 268-273

Scott RB, Shortland AJ, Degryse P, Power M, Domoney K, Boyen S, Braekmans D (2012) The analysis of in-situ 17th century painted glass from Christ Church Cathedral, Oxford. Glass Technol-Part A 53:65-73

Shugar AN, Mass JL (eds) (2012) Handheld XRF for art and archaeology, studies in archaeological sciences 3. Leuven University press, Leuven

Soliman MM (1980) Geochemistry of some granodiorites, granites, pegmatites and associated gneisses from Aswan, Egypt. In: Moustafa GA (ed) Proceedings of the International Meetings Held on the Occasion of the Fifth Conference of African Geology, Cairo 6-11 October, 1979, Annals of the Geological Survey of Egypt 10. Geological Survey of Egypt and Mining Authority, Cairo, pp 611626

Speakman RJ, Little NC, Creel D, Miller MR, Inanez JG (2011) Sourcing ceramics with portable XRF spectrometers? A comparison with INAA using Mimbres pottery from the American Southwest. J Archaeol Sci 38:3483-3496

Telford WM, Geldart LP, Sheriff RE (1990) Applied geophysics, 2nd edn. Cambridge University Press, Cambridge

Tykot RH (2004) Scientific methods and applications to archaeological provenance studies. In: Martini M, Milazzo M, Piacentini M (eds) (2004) Physics methods in archaeometry, course CLIV. Proceedings of the International School of Physics "Enrico Fermi", Varenna on Lake Como, Villa Monastero, 17-27 June 2003. IOS Press, Amsterdam, pp 407-432

Versluys MJ (2002) Aegyptiaca Romana. Nilotic scenes and the Roman views of Egypt, Religions in the Graeco-Roman world 144. Brill, Leiden

Versluys MJ, Leemreize M, Mol E, Müskens S, Van Aerde M (2014) L'Egitto a Roma. Forma Urbis XIX.9: 17-19

Walker S, Higgs P (2001) Cleopatra of Egypt. From history to myth. British Museum Press, London 